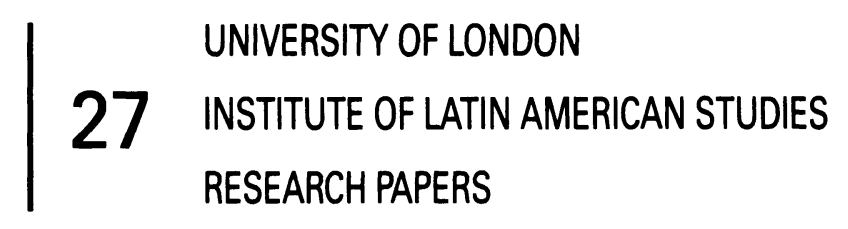

\title{
A Long-Run Model of Development for Central America
}

Victor Bulmer-Thomas 



\section{A Long-Run Model of Development for Central America}

\section{Victor Bulmer-Thomas}




\section{British Library Cataloguing-in-Publication Data}

Bulmer-Thomas, V. (Victor), 1948-

A long-run model of development for Central America.

I. Title

330.972805

ISBN 0901145769

ISSN 09577947

(c) Institute of Latin American Studies

University of London 1991 


\section{CONTENTS}

Introduction $\quad 1$

Stabilisation and Adjustment Programmes 5

$\begin{array}{ll}\text { Model Assumptions } & 14\end{array}$

Objectives of the Model 22

Constraints on the Model 24

$\begin{array}{ll}\text { A Counterfactual Experiment } & 27\end{array}$

Policies and Instruments $\quad 31$

Trade with the Rest of the World 34

Regional Cooperation $\quad 38$

The Internal Market $\quad 47$

$\begin{array}{ll}\text { Conclusions } & 50\end{array}$

$\begin{array}{ll}\text { Notes } & 54\end{array}$ 
Victor Bulmer-Thomas is Professor of Economics at Queen Mary and Westfield College, University of London, and an Associate Fellow of the Institute of Latin American Studies. 


\section{A Long-Run Model of Development for Central America}

\section{Introduction}

It is customary to refer to the 1980 s in Latin America as 'the lost decade' in recognition of the heavy price paid by the region in terms of falling living standards as a result of the debt crisis. Central America has also suffered from the debt crisis, but in addition has had to cope with the effects of war, massive displacements of refugees and several natural disasters. Thus, for Central America the 1980s has been more than a lost decade; it represents perhaps the worst crisis in its post-independence history. As Table 1 shows, GDP per head in 1990 was still below the level recorded in 1980 in all five republics and the cumulative decline in Nicaragua was over 40 per cent.

Under these circumstances, the task of economic and social reconstruction in the 1990s acquires overwhelming importance. Yet here again Central America faces special problems. The impressive growth rates in Central America in the three decades after $1947 / 8$ were based on an economic model which collapsed in the 1980s and which cannot be restored in the 1990s. Thus, the task of reconstruction in the 1990s can only be achieved on the basis of a new model.

The pre-1980 economic model rested on three pillars. ${ }^{1}$ The first pillar was the rapid growth of traditional agroexports (above all, coffee, bananas, cotton, beef and sugar); earnings from these exports underpinned the region's exchange rates, making possible a regime of fixed dollar exchange rates which put Central America in effect on a dollar standard (the second pillar); the combination of buoyant extraregional exports and the dollar standard made possible the rapid growth of intraregional trade through the Central American Common Market (the third pillar).

The collapse of the first pillar in the 1980s is unlikely to be a temporary phenomenon. While traditional agroexports will of course continue to play a major part in Central American economic activity, they are unlikely to play a dynamic role; yet the region desperately needs sources of dynamism to raise living standards quickly in the 1990s. Problems of market access (e.g. sugar), costs (e.g. cotton) and ecology (e.g. beef) suggest that the best that can be expected from traditional agroexports is slow growth in both volume and value terms. Only in the case of bananas are the medium-term prospects favourable as a result of the opening of the Eastern European market on the one hand and 
on the other the move to a single market in the European Community after 1992. ${ }^{2}$

\section{TABLE 1}

REAL GROSS DOMESTIC PRODUCT PER HEAD (1988 US DOLLARS)

$\begin{array}{llcccc} & \begin{array}{l}\text { Costa } \\ \text { Rica }\end{array} & \begin{array}{l}\text { El } \\ \text { Salvador }\end{array} & \begin{array}{l}\text { Guate- } \\ \text { mala }\end{array} & \text { Honduras } & \text { Nicaragua } \\ \mathbf{1 9 8 0} & 1759 & 1325 & 1085 & 1015 & 1097 \\ \mathbf{1 9 8 1} & 1670 & 1177 & 1062 & 992 & 1124 \\ \mathbf{1 9 8 2} & 1505 & 1079 & 996 & 936 & 1078 \\ \mathbf{1 9 8 3} & 1500 & 1082 & 944 & 899 & 1082 \\ \mathbf{1 9 8 4} & 1571 & 1093 & 922 & 890 & 1015 \\ \mathbf{1 9 8 5} & 1538 & 1096 & 891 & 892 & 935 \\ \mathbf{1 9 8 6} & 1577 & 1086 & 867 & 890 & 886 \\ \mathbf{1 9 8 7} & 1605 & 1092 & 872 & 907 & 848 \\ \mathbf{1 9 8 8} & 1614 & 1088 & 879 & 923 & 734 \\ \mathbf{1 9 8 9} & 1659 & 1062 & 887 & 906 & 689 \\ \mathbf{1 9 9 0} & 1676 & 1069 & 888 & 871 & 629 \\ \mathbf{1 9 8 1 - 9 0} & -4.7 \% & -19.3 \% & -18.2 \% & -14.2 \% & -42.7 \% \\ \mathbf{( C u m u l a t i v e} & & & & & \end{array}$

Sources: Inter-American Development Bank, Economic and Social Progress in Latin America, 1990 Report, Washington DC., 1990 for 1980 to 1988. For 1989 and 1990, the figures have been derived from United Nations, Economic Commission for Latin America and the Caribbean, Preliminary Overview of the Economy of Latin America and the Caribbean, Santiago, December, 1990.

If traditional exports cannot be relied on to generate the necessary increases in foreign exchange reserves, then the search has to begin for new sources of export dynamism. Non-traditional exports, however, are sensitive to the exchange rate and require - particularly in the early stages - real exchange rate 
depreciation. Thus, a regime of fixed nominal exchange rates is not realistic for the 1990s.

The Central American Common Market (CACM) cannot therefore be reestablished on its old basis; the dollar standard has collapsed and traditional exports cannot be relied upon to provide the hard currency to finance imbalances in intraregional trade. This does not mean that the CACM does not have a role to play in the reconstruction of Central America in the 1990s, but it does mean that regional integration will have to rest on new foundations. The old foundations have been destroyed and cannot be restored.

There are other problems which the reconstruction of the Central American economies will have to face in the 1990s. The growth model of the pre-1980 period was successful when judged by the rise in Gross Domestic Product (GDP) per head, but much less successful when judged by changes in income distribution, reduction in poverty and other social indicators. In the 1980 s there is widespread agreement that these problems have become worse; indeed, some studies on poverty suggest that, far from being a 'marginal' phenomenon, it is very widespread, affecting more than half the population throughout the region and more than 70 per cent in Guatemala. ${ }^{3}$ Clearly, a new economic model for Central America in the 1990s which did not address the poverty issue explicitly would be seriously at fault.

The same is true of environmental questions. The pre-1980 economy growth in Central America took place with little regard for ecological issues and the maintenance of the environment; in effect, the environment was treated (as in so many countries) as a free resource to be exploited at will. The result was serious depletion of the forest cover, pollution of rivers and lakes and the first signs of soil exhaustion in some agricultural areas. The problem in Central America is not as serious as in some other Latin American countries (e.g. Haiti), but a new economic model for the region cannot continue to treat the environment as a free resource. ${ }^{4}$

While research in the social sciences has revealed a clearer understanding of the costs and benefits of the pre-1980 model, the decade of the 1980s has added a series of economic problems which were not present before. Outstanding among these are the debt problem, the friction between the private and public sectors and the rise of un- and under-employment.

In 1982, the year of the threatened Mexican default, only Costa Rica and Nicaragua were acknowledged to have a debt problem. Since then, all five republics have run into difficulties with their debt service payments, to the point where the accumulation of arrears had become the rule rather than the 
exception by the end of the 1980s. The application of the Brady Plan for debt reduction to Costa Rica in 1990 has brought debt relief to one country in the region, but the others still have some way to go before the debt crisis can be put behind them. ${ }^{5}$ Indeed, the external debt in Nicaragua jumped from some $\$ 2$ billion in 1980 to nearly $\$ 9$ billion in 1990 - 27 times greater than the value of exports in that year.

By contrast, the lack of confidence between the private and public sectors although not immune to outside pressures - has been primarily a Central American phenomenon. The private sector in the 1980s accused the public sector of waste, inefficiency and incompetence and called for a smaller state, while the public sector deplored the short-term vision of the private sector and its alleged preference for capital flight over long-term investment. Clearly, this friction was in large part a reflection of the economic crisis of the 1980s, but it was also a cause of the economic problems. By the beginning of 1991, however, governments with the support and approval of the private sector had come to power in all five countries and the relationship between the private and the public sector began to improve.

A necessary condition for growth in the 1990s is the completion of stabilisation programmes; a 'dash for growth' before stabilisation is completed would be a recipe for disaster. Stabilisation programmes began as early as 1980 (in Costa Rica), but even now are still not complete in any of the republics; some would argue, therefore, that it is inappropriate to discuss the content of long-run models while the battle for stabilisation still has to be won. This is very misleading. Stabilisation programmes, by definition, focus on the shortterm with policies designed to restore internal and external equilibrium. These short-term measures, however, sometimes have long-term implications; this means that a long-run model may be implicit in a stabilisation programme although the authorities are not necessarily conscious of this and indeed may not approve of the long-run consequences. A good example of a short-term stabilisation programme with long-run implications (albeit one that the authorities welcomed) is the reaction to the 1929 depression in the larger Latin American republics; the measures taken to restore external equilibrium provided the framework for import-substituting industrialisation over the longrun.

Given that short-term stabilisation policies can have long-run implications, it makes sense to have a vision of the future to avoid inconsistencies. In addition, many outside actors in Central America (notably the World Bank) have a very clear vision of the region's future; there is nothing wrong with this - indeed, one would expect nothing less from a prestigious international agency - but at the end of the day Central America's future needs to be determined by 
Central Americans. In turn, that requires the adoption of a long-run model by the region's leaders. Such a model may have many features in common with the models proposed by outside agencies, but it is unlikely to correspond exactly.

Thus, the need for a long-run model cannot be dispensed with simply because stabilisation and adjustment programmes are still incomplete. At the same time, the design of stabilisation and adjustment programmes needs to take into account the long-run model. It is appropriate, therefore, to examine the record on stabilisation in Central America in order to see what lessons can be learned.

\section{Stabilisation and Adjustment Programmes}

More than a decade has passed since the first stabilisation programmes were adopted in Central America to cope with the series of external and internal shocks which struck the region at the end of the 1970s. ${ }^{6}$ Since stabilisation is widely recognised as an essential precondition for adjustment programmes leading to sustainable long-run growth, the importance of successful stabilisation cannot be overemphasised. No Central American country can afford to repeat the fall in living standards experienced in the 1980 s, so that growth of real income per head in the 1990s is the highest priority. Yet the basis for sustainable long-run growth in the current decade will be fragile if stabilisation has not been completed successfully.

Despite numerous attempts at stabilisation, not one of the five Central American countries has yet succeeded in laying a really solid foundation for stable and sustainable growth. Even in Costa Rica, the republic which has made the most progress on policy reform, the annual growth rate of real Gross Domestic Product (GDP) fluctuates widely with a year of fast growth (approximately five per cent) being followed by one of slow growth (less than three per cent) as the economy runs up against numerous constraints which past stabilisation and adjustment programmes have failed to remove.

One of the consequences of the failure of stabilisation has been a dismal growth record. Not a single country - not even Costa Rica - had recovered the 1980 level of real GDP per head by 1990. Although the 1980s was the 'lost decade' for all Latin America, the drop in living standards was more severe in Central America with the four northern republics all recording a fall in real GDP per head through the 1980s which was faster than the Latin American average, while Nicaragua recorded the most dramatic decline (five per cent per year from 1981 to 1989) of any Latin American republic.? 
Throughout the region, internal disequilibrium - manifested in budget deficits and high rates of inflation - remains a problem. The same is true, however, of external disequilibrium which is reflected in trade and current account deficits in the balance of payments. Furthermore, the situation is in some respects worse than a decade ago, since all republics now suffer from double digit annual inflation rates and the chances of funding balance of payments deficits with official capital flows are receding as the Bush administration in the United States - the principal source of lending to the region - adjusts its official lending policy to the geopolitical realities of the post-cold war era. ${ }^{8}$ Thus, an unchanged current account deficit may imply an even greater external disequilibrium than before as a result of the expected decline in official capital flows from the major donor.

In small countries with poorly developed capital markets - as is the case in Central America - the fiscal position is often a crucial determinant of internal disequilibrium. Even a relatively modest budget deficit (expressed as a proportion of GDP) can lead to inflationary pressures as a result of the monetary implications of deficit financing. Thus, an important test of stabilisation programmes in Central America has to do with fiscal policy.

Since many republics in Central America went into the 1980s with a ratio of government revenue to GDP which was low by international standards, an increase in this ratio might have seemed an appropriate way to implement a tighter fiscal policy leading to internal equilibrium. Yet, as Table 2 shows, the ratio was either stationary or falling in the last years of the 1980s. Indeed, El Salvador and Guatemala ended the decade with a ratio below ten per cent, which is among the lowest in Latin America. In Nicaragua, despite draconian tax increases in the first years of the Sandinista regime, the ratio fell sharply after 1984 as the high and accelerating rate of inflation eroded the real value of tax receipts and the burden of taxation was offset in part through delayed payments. ${ }^{9}$

Even more disturbing than the ratio of government revenue to GDP has been the composition of revenue itself. In a region long noted for its dependence on indirect (including trade) taxes and for its small number of direct taxpayers, an increase in the proportion of government revenue from income and/or property taxes might have seemed an appropriate route to fiscal orthodoxy. Yet the opposite in general has happened. In three republics (El Salvador, Honduras and Guatemala) the proportion was lower in 1989 than in 1980 and in Costa Rica the proportion has been falling since 1983. Only Guatemala has managed to increase this ratio, but it is still one of the lowest in the region since the republic started from such a low base (14 per cent in 1980). 


\section{TABLE 2}

\section{CENTRAL GOVERNMENT REVENUE AS A PERCENTAGE OF GDP}

$\begin{array}{llcccc} & \begin{array}{l}\text { Costa } \\ \text { Rica }\end{array} & \begin{array}{l}\text { El } \\ \text { Salvador }\end{array} & \begin{array}{l}\text { Guate- } \\ \text { mala }\end{array} & \text { Honduras } & \text { Nicaragua } \\ \mathbf{1 9 8 0} & 12.8 & 11.4 & 9.5 & 14.9 & 21.3 \\ \mathbf{1 9 8 1} & 13.6 & 12.8 & 8.6 & 13.4 & 24.1 \\ \mathbf{1 9 8 2} & 14.4 & 12.3 & 8.4 & 13.4 & 25.3 \\ \mathbf{1 9 8 3} & 16.6 & 12.4 & 7.8 & 13.3 & 30.9 \\ \mathbf{1 9 8 4} & 16.6 & 13.2 & 7.3 & 15.1 & 34.9 \\ \mathbf{1 9 8 5} & 16.2 & 13.4 & 7.7 & 15.6 & 32.1 \\ \mathbf{1 9 8 6} & 15.4 & 14.4 & 8.9 & 15.6 & 32.0 \\ \mathbf{1 9 8 7} & 15.7 & 11.9 & 9.4 & 16.3 & 27.7 \\ \mathbf{1 9 8 8} & 15.2 & 10.4 & 10.1 & 16.1 & 20.5 \\ \mathbf{1 9 8 9} & 15.0 & 8.2 & 9.2 & 15.6 & 18.9\end{array}$

Source: Inter-American Development Bank, Economic and Social Progress in Latin America, 1990 Report, Washington DC., 1990, Table C-1, p. 275

The failure to raise the ratio of government revenue to GDP has forced those responsible for the design of stabilisation programmes to put greater emphasis on cutting expenditure as the means to reduce budget deficits. Certainly substantial progress has been achieved in all republics in reducing the ratio of expenditure to GDP, but in far too many cases the reduction has come through cuts in public investment (including health and education). Since there is a growing recognition (even in neoliberal circles) of the complementarity of public and private investment, the opportunity cost of cutting expenditure through reducing public capital formation is high. Indeed, in some republics (e.g. El Salvador) public investment has fallen to the point where negative 'crowding in' is far more of a danger than 'crowding out'. ${ }^{10}$

The cuts in government expenditure in Nicaragua were not sufficient, at least until 1989, to prevent the emergence of a massive budget deficit which was the prime cause of accelerating inflation. In 1988 the Sandinista regime had the dubious distinction of presiding over the highest annual rate of inflation $(33,603$ per cent) ever recorded in Latin America. Elsewhere, budget deficits as a proportion of GDP were lower at the end of the decade than at the beginning, 
but the inflationary implications were still considerable and the size of the fiscal deficit was a major factor behind the increase in the cost of living index in all republics (see Table 3). Indeed, Guatemala and Honduras began the new decade with rates of inflation higher than ever recorded since the 1940s.

TABLE 3

ANNUAL RATES OF INFLATION (\%). DECEMBER TO DECEMBER

$\begin{array}{llcccc} & \begin{array}{l}\text { Costa } \\ \text { Rica }\end{array} & \begin{array}{l}\text { El } \\ \text { Salvador }\end{array} & \begin{array}{l}\text { Guate- } \\ \text { mala }\end{array} & \text { Honduras } & \text { Nicaragua } \\ \mathbf{1 9 8 2} & 81.7 & 13.8 & -2.0 & 8.8 & 22.2 \\ \mathbf{1 9 8 3} & 10.7 & 15.5 & 15.4 & 7.2 & 35.5 \\ \mathbf{1 9 8 4} & 17.3 & 9.8 & 5.2 & 3.7 & 47.3 \\ & & & & & \\ \mathbf{1 9 8 5} & 11.1 & 30.8 & 31.5 & 4.2 & 334.3 \\ \mathbf{1 9 8 6} & 15.4 & 30.3 & 25.7 & 3.2 & 747.4 \\ \mathbf{1 9 8 7} & 16.4 & 19.6 & 10.1 & 2.7 & 1347.4 \\ \mathbf{1 9 8 8} & 25.3 & 18.2 & 11.0 & 6.7 & 33602.6 \\ \mathbf{1 9 8 9} & 10.0 & 23.5 & 20.2 & 11.4 & 1690.0 \\ \mathbf{1 9 9 0} & 22.4 & 19.9 & 50.1 & 25.3 & 8500.0\end{array}$

Source: United Nations, Economic Commission for Latin America and the Caribbean, Preliminary Overview of the Economy of Latin America and the Caribbean 1990, Santiago, December 1990, Table 5.

The poor fiscal record did not reflect the lack of attempts at fiscal reform as much as the failure of such attempts. In Guatemala, for example, the efforts of the Cerezo administration (1986-90) at tax reform were largely undermined by the opposition of a well-organised private sector. In Costa Rica, numerous attempts were made in the 1980 s to improve the efficiency of tax collection, but the fiscal privileges offered to exporters of non-traditional products tended to overwhelm the modest tax gains achieved under President Monge (1982-86) and President Arias (1986-90).

In Nicaragua any prospects of tax reform were undermined by the acceleration of inflation which - as already argued - eroded the real value of tax receipts and gave taxpayers a strong incentive to delay payments. Not a single country made any progress on negotiations with the US government which 
might have led to taxation agreements affecting flight capital to Miami and other US cities.

The problem of internal disequilibrium has been aggravated by the political constraints on tax reform and the lack of consensus on the appropriate measures to take to reduce budget deficits. By contrast, there has been widespread acceptance that external disequilibrium should be tackled by measures to promote exports rather than suppress imports. Painful choices have arisen, however, as soon as the policy debate has moved from the general question of export promotion to the specifics of how to achieve it.

Among the International Financial Institutions (IFIs), such as the World Bank and the International Monetary Fund, there is a conviction that the most appropriate way to promote exports is through a depreciation of the real effective exchange rate (REER), trade liberalisation and the encouragement of direct foreign investment (DFI). These three ingredients, part of the so-called Washington consensus ${ }^{11}$, have met with a mixed reception in Central America.

The commitment to depreciation of the REER has proved to be a painful pill to swallow for several reasons. First, in small open economies (such as in Central America) the depreciation of the nominal exchange rate has an important bearing on the rate of inflation; thus, a small depreciation of the REER usually requires a large nominal devaluation with serious inflationary implications. Secondly, the five republics of Central America had a long history before the 1980s of relative exchange rate stability with currencies pegged to the US dollar; this nominal anchor had proved extremely useful in stimulating productive investment, avoiding capital flight and reducing currency transaction costs.

Not surprisingly, exchange rate policy in Central America has been fraught with problems in the last decade. Honduras only abandoned its fixed nominal rate (unchanged since 1918) in 1990; Guatemala has oscillated between devaluing the exchange rate to promote exports and intervening to control inflation; Nicaragua's devaluations, both under the Sandinistas and President Chamorro, have tended to be too little too late; the Cristiani administration in El Salvador was at first wary of freeing the exchange rate because of the possible impact on inflation - only to find that capital inflows from remittances, reverse capital flight and IFIs were producing an equilibrium exchange rate that was almost certainly overvalued in relation to the requirements of export promotion. ${ }^{12}$ Only in Costa Rica has a consistent exchange rate policy been pursued, providing exporters with a stable REER after an initial real depreciation in the first half of the 1980s. 
Trade liberalisation has been equally problematic. The Common External Tariff (CET), a requirement of the Central American Common Market (CACM), had been revised in the mid-1980s, but both the average tariff rate and tariff dispersion were considered too high by the IFIs. Under its Structural Adjustment Loans (SAL), the World Bank was able to persuade Costa Rica to break ranks and reduce tariffs unilaterally; similar steps were taken in El Salvador and Honduras, but tariff policy in the region is no longer harmonised (although the Presidential summit in San Salvador in July 1991 did at least set a future date for harmonisation). Furthermore, measures to liberalise extraregional imports have often been matched by additional restrictions on intraregional trade so that the recovery of the CACM has been delayed longer than necessary.

Policies towards DFI have been generally liberal. In Nicaragua, the Sandinistas vacillated for years over the adoption of a Foreign Investment Law, but the lack of interest on the part of private investors made the debate rather sterile. However, Central America has traditionally adopted liberal policies towards DFI and the problem since the end of the 1970s has been a reluctance on the part of foreign investors to invest in a region perceived as politically unstable at the same time as other regions have become increasingly attractive.

Again, it is no surprise to find that the record on external disequilibrium has been rather patchy. Costa Rica has enjoyed considerable success in the promotion of non-traditional exports, but the high (and rising) propensity to import has left a gap in the current account which is almost as large as at the beginning of the 1980s. The strong exchange rate in El Salvador is making it hard for many industrialists and farmers to adjust to the shock of trade liberalisation. The experiment with neoliberal policies in Honduras under President Callejas threatens to be short-lived as the losers from trade liberalisation and REER depreciation prove to be far more vocal than the winners.

Just as in many other parts of Latin America, serious efforts have been made to introduce policy reform, to implement stabilisation packages and to adopt adjustment programmes in Central America. It would be harsh indeed not to recognise the enormous sacrifices demanded of the Nicaraguan people in the name of stabilisation both under the Sandinistas in 1988-89 and under President Chamorro in 1990-91. Similarly, the Cristiani government in El Salvador deserves credit for the courageous way in which it has tackled both stabilisation and adjustment since coming to power in mid-1989. Yet, at the beginning of the 1990 s, it is difficult to say with confidence that a single country has so far truly laid the solid foundation needed for fast growth in the next decade. 
Numerous explanations can be found for the lack of progress in implementing successful stabilisation and adjustment programmes in Central America. The fragile social and political situation in all republics except Costa Rica has encouraged policy makers to postpone awkward decisions as long as possible. In the case of internal disequilibrium, measures to tackle budget deficits and accelerating inflation can be postponed almost indefinitely, for a government is only forced to act (as the Sandinistas found to their cost) as hyperinflation approaches. External disequilibrium, on the other hand, must be addressed unless the country concerned has access to sufficient capital inflows to finance the deficit or is prepared to ration the limited supply of foreign exchange through draconian import controls. Both alternatives were widely adopted in Central America in the 1980s, with El Salvador and Honduras in particular using official capital inflows to postpone harsh decisions and Nicaragua being the most dependent on foreign exchange rationing.

A second problem has been the lack of consensus on the appropriate measures to take. The bitter debates over exchange rate policy in Honduras and tax reform in Guatemala have already been mentioned. Nicaragua under the Sandinistas could not reach consensus on foreign investment. The issue of land reform in El Salvador has proved deeply divisive and the lack of consẹnsus has had numerous implications for adjustment and stabilisation. Even in Costa Rica, where consensus on export promotion has at least been achieved, there remain numerous divisions over tax reform and financial liberalisation. Furthermore, constitutional rigidities in Costa Rica have often prevented the executive from implementing a consistent policy even when a broad consensus has existed.

A third, and widespread, problem has been the reluctance to tackle all aspects of stabilisation and adjustment simultaneously. Although such 'general equilibrium' solutions are generally recognised to be preferable, they have been abandoned in favour of 'partial equilibrium' solutions in which progress has been made on a limited number of fronts. Yet partial equilibrium solutions in one area can aggravate problems in other areas. For example, the use of fiscal incentives to promote non-traditional exports undermines the fiscal position; rapid trade liberalisation (through tariff reductions) can also weaken government revenue; the commitment to a stable REER damages price stability, and so on.

The public external debt also proved to be an obstacle in the path of successful stabilisation for much of the past decade. At best a time-consuming distraction for hard-pressed government officials, the public sector's purchases of scarce foreign exchange to service foreign debt have distorted government expenditures while widening balance of payments current account deficits. Although the burden of the public external debt has not been as severe in 
Central America as in some other Latin American republics, it has to be remembered that the region has been extremely ill-equipped to cope with even a modest debt problem - let alone a major debt crisis.

Finally, there has been conflict between adjustment and stabilisation programmes themselves. With the renewal of growth becoming the overriding priority throughout the region and with adjustment needed to underpin stable and high growth rates, there has been an understandable desire to launch adjustment programmes before the process of stabilisation has been completed. These programmes, with their emphasis on a change in relative prices to encourage resources to shift into new activities, and the adoption of appropriate incentives, can aggravate stabilisation problems - as Costa Rica has found to her cost on numerous occasions in the last decade.

The above analysis of the failures and disappointments of stabilisation and adjustment programmes suggests that a key problem is the inconsistency which arises from trying to do too much too quickly. The crisis in Central America has so many dimensions that it is easy to lose sight of the main priorities. Furthermore, the crisis has affected the confidence of the policy-making elite in all republics, leaving them vulnerable to pressure from outside interests. These pressures have led to a widening of the reform agenda in directions which might be desirable under more normal circumstances, but which - in the Central American context - create unrealistic expectations.

The first priority is to subordinate stabilisation and adjustment programmes to a long-run growth model for the region. Such a model, outlined in the following sections, should have at least four dimensions: (a) the promotion of non-traditional exports to the rest of the world, (b) the recovery and strengthening of the CACM, (c) the exploitation of new opportunities for traditional exports arising from the formation of market economies in Eastern Europe and the move to a Single Domestic Market in the European Community, and (d) the broadening of the internal (national) market through a reduction in poverty and an improvement in income distribution.

The design of stabilisation and adjustment programmes consistent with such a long-run model would have two crucial ingredients: fiscal policy and exchange rate policy. These are the two elements which any Central American republic ignores at its peril. Other items on the reform agenda (e.g. privatisation, deregulation and financial liberalisation) can be added once success has been achieved in the two priority areas.

Prudent fiscal policy suggests modest budget deficits. With further expenditure cuts (except on debt service payments and defence) so hard to 
achieve, the emphasis must be put on raising revenue. Here the problem is NOT the introduction of an array of new taxes so much as the enforcement of existing taxes. Where tax reductions or exemptions are introduced as part of the incentives in adjustment programmes, they need to be matched by additional revenue from other sources.

The need for fiscal discipline arises for a number of reasons. With nominal exchange rate devaluation expected for some years to come (see below), a tight fiscal policy is necessary to moderate the increase in domestic prices. At the same time, the need to broaden social expenditure through careful targeting of groups most in need will be self-defeating if the additional expenditure is financed through inflationary borrowing techniques. Tight fiscal policy cannot eliminate inflation in Central America, but loose fiscal policy - as Nicaragua has found to her cost - will certainly exacerbate inflationary pressures.

The need to give priority to exchange rate policy arises from the crucial role which competitive exchange rates play in the promotion of exports. Thus, an initial devaluation of the REER needs to be followed by an exchange rate policy which at least maintains a stable real exchange rate. Unless exporters are confident that the REER will be stable or falling, they are most unlikely to undertake the investments required to shift resources towards the export sector. Other measures to promote exports will be ineffective unless exchange rate policy is consistent.

Even a stable REER implies - in the Central American context - a rise in domestic prices as a result of nominal devaluations. Thus, price stability is not an option in the medium-term. New measures must be taken (including targeted social expenditure) to protect the poorest groups in society from the impact of price rises, so that a stable REER implies the use of some government subsidies. These will quickly lead to fiscal indiscipline unless matched by tax increases. Thus, exchange rate and fiscal policy need to complement each other and must be operated in harmony.

Narrowing of the reform agenda in the first instance to fiscal and exchange rate policy may not sound very ambitious, but we have already seen the consequences of over-ambitious reform programmes. Once these two crucial areas of policy reform are established and credible, the reform agenda can be widened. Trade liberalisation should aim both to lower tariff protection and to reestablish the CET, while immediate steps need to be taken to eliminate all non-tariff barriers on trade within the CACM. Financial liberalisation should set positive real interest rates as a minimum goal and property rights for small farmers need to be strengthened as early as possible. 


\section{Model Assumptions}

The framework within which each Central American country develops in the 1990s will be affected by the regional and international outlook. These two dimensions (regional and international) will act as a crucial constraint on the pace and character of development in Central America in the next decade. It is therefore necessary to address these questions explicitly and to make clear what assumptions are being made.

First, it is necessary to assume that at the regional level Central America moves towards peace. This is a critical assumption. Without peace in the region, there is little possibility of growth, and development will continue to be distorted by the needs of a war economy. Fortunately, this assumption has become much more realistic at the beginning of the 1990s with the disbandment of the contras in Nicaragua, the negotiations towards an end to the civil war in El Salvador and the initiation of a process of dialogue in Guatemala. Although much progress remains to be made, the prospects for genuine and lasting peace are better than at any time in the last decade. The Bush administration has shown itself more flexible in its relations with Central America than its predecessor, the end of the Cold War has undermined the alleged Soviet threat and the electoral defeat of the Sandinistas in Nicaragua in February 1990 has removed a major source of regional tension.

The implications of this assumption are enormous. It means that the allocation of public investment and new spending on social infrastructure can be determined by economic rather than military considerations. It also means that the huge numbers of Central Americans currently displaced within the region can begin to return to their original homes and that the size of the armed forces can be reduced with a corresponding addition to the productive labour force.

However, the assumption of peace also means that some of the international capital flows which have helped to finance the balance of payments current account deficits in the 1980 s will cease. Those loans or grants given to the region for geopolitical reasons will decline in importance as regional tensions diminish. This is true both of support given by some western countries and of the support given to Nicaragua by the Soviet Union. Furthermore, events in Eastern Europe will not only lead to a reduction in aid from some countries to Nicaragua, but will also lead to competition for scarce resources since there is no guarantee that funds for Eastern Europe will necessarily be additional to those allocated to other regions by the major aid donors. 
The balance of payments position in the 1980s is summarised in Table 4 . With the exception of Nicaragua, most countries ran a small deficit on merchandise trade. The current account deficit, however, was generally much larger since interest payments on debt and other service payments were not matched by net receipts of transfers; the exception is El Salvador, where net transfers have been the most important source of balance of payments support as a result of remittances and US aid. Private capital flows, whether direct or portfolio, were generally unimportant (see Table 4) so that the current account deficit had to be financed in the main by net capital inflows.

The deficit on merchandise trade in the 1990s will need to increase if Central America is going to recover the living standards of the late 1970s. This is true despite an expected improvement in export earnings, since the marginal propensity to import remains and will remain very high. Thus, for the five republics taken together the annual merchandise deficit consistent with economic recovery in the 1990 s is likely to be between $\$ 1.5$ and $\$ 2$ billion, implying an increase in the merchandise deficit of around $\$ 1$ billion. This is a substantial increase which will not be easy to finance, although any failure to do so is likely to result in a reduction in the pace of economic recovery. It therefore raises the question of how it can be funded.

One source of relief is likely to be debt reduction by commercial banks. Whether this comes to Central America as part of a solution under the Brady Plan (as has recently been negotiated for Costa Rica) or through a package put together by the United Nations-sponsored Programa Especial para Centroamérica (PEC) does not matter; in addition, as part of the debt negotiations, interest payments on the debt will decline either through reduction of the principal or through reduction of interest rates or both.

A price will have to be paid, however, for debt reduction. The bigger the discount, the more unlikely that the commercial banks will play a significant part in the reconstruction of Central America in the future. This is not an argument against debt reduction, since the commercial banks have shown that they are most reluctant to play a significant role in the region even without debt relief, but it does mean that Central America cannot rely on the banks to provide the balance of payments support which a long-run model is likely to require. Furthermore, the interest payments in Table 4 are largely theoretical since they represent the interest owed rather than the interest paid; in practice, by the end of the 1980s arrears of both principal and interest payments were substantial in the case of all Central American republics so that any debt relief negotiated with commercial banks is not likely to make much difference to actual payments. 
造

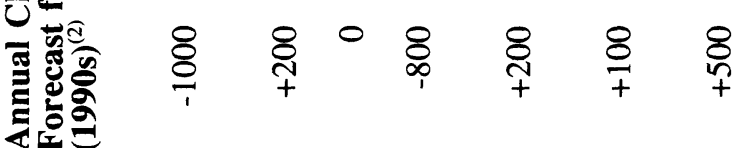

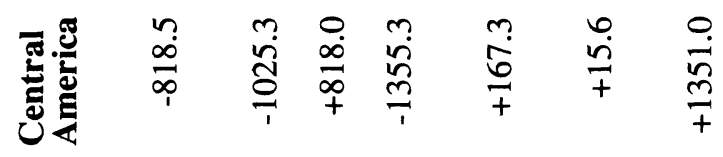

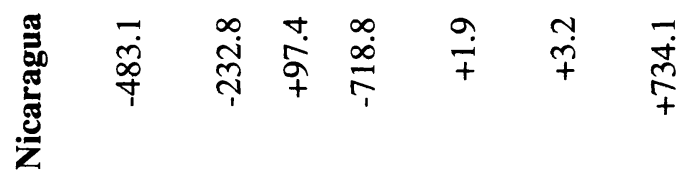

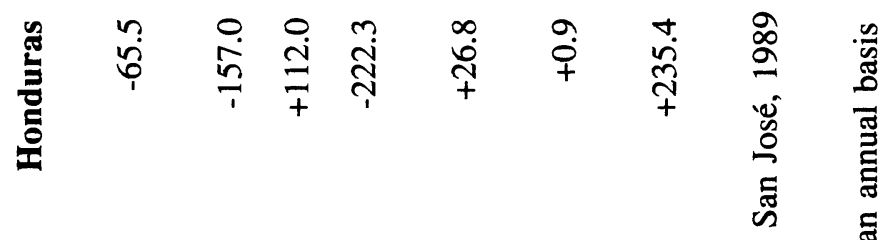

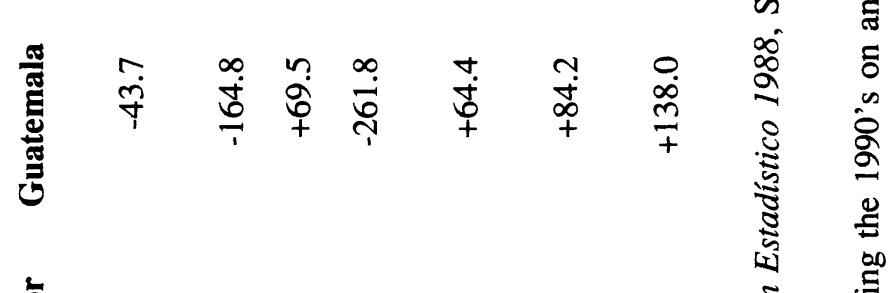

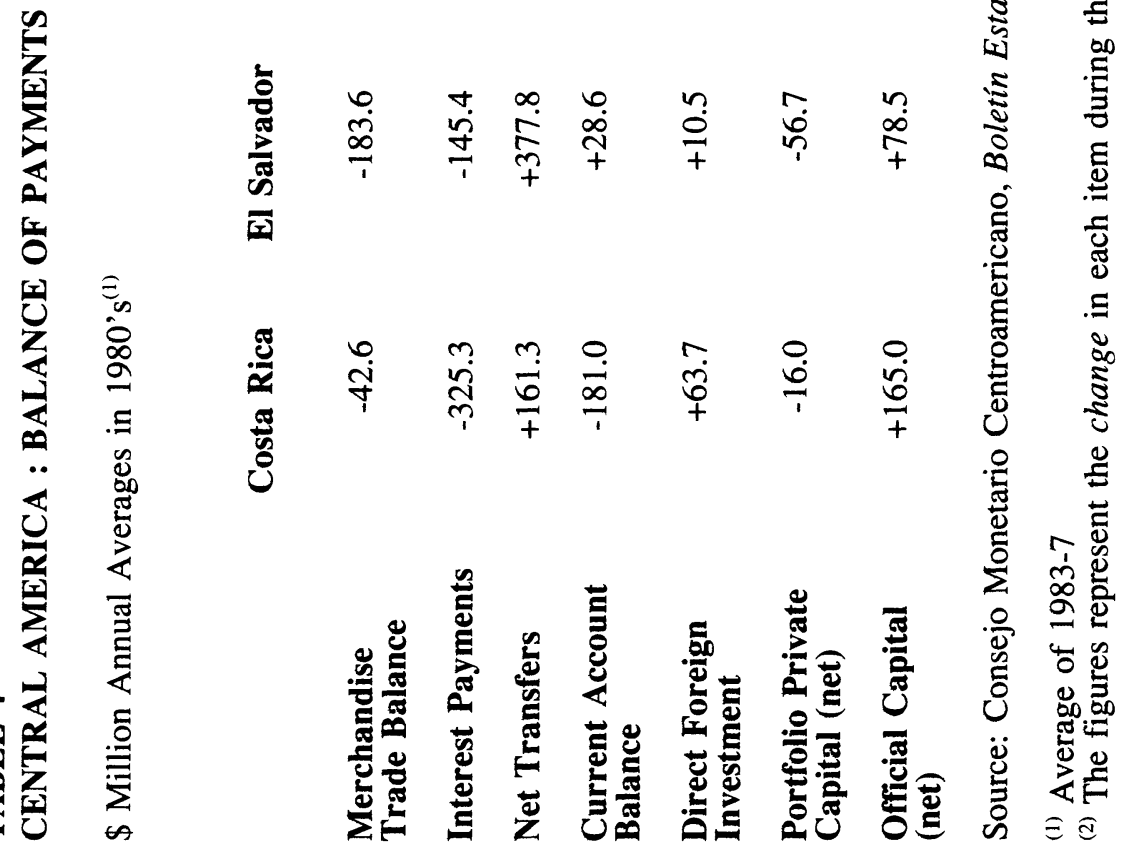


Another area of debt relief is through negotiations with the Paris Club of official creditors. Until recently, the Paris Club had extended debt relief only to African countries; however, early in 1990 the principle was extended to Bolivia so that Central America may be eligible in the 1990 s for some reduction of debt service payments owed to official creditors. Since debt owed to official creditors has been serviced more promptly than debt owed to private creditors, debt relief under the aegis of the Paris Club could bring a genuine saving of foreign exchange and reduce, ceteris paribus, the size of the current account deficit needing to be financed by net capital flows.

The size of the region's annual current account deficit will be determined primarily by changes in the merchandise balance, interest payments and net receipts of transfers; while official transfers may decline - since some of the payments are determined by security considerations - private transfers may increase since they are determined above all by the level of remittances. Thus, it is safest to assume no change in net receipts of transfers so that the increase in the annual current account deficit in the 1990s consistent with economic recovery can be set at around $\$ 800$ million. This can only be financed if there is an increase in capital inflows.

An increase can certainly be expected in direct foreign investment (DFI). This item in the balance of payments suffered grievously in the last decade (see Table 4) as a result of the economic crisis on the one hand and political instability on the other. In the superior economic and political climate of the 1990 s, underpinned by policies designed to promote exports, it is safe to predict that DFI will recover. However, too much should not be read into this. The base flows for DFI are so low that even a sharp recovery in percentage terms will not be sufficient to solve the financing problem. The most realistic assumption is that the proportion of the current account deficit financed by DFI will slowly rise in the 1990 s, leading to an average annual increase of $\$ 200$ million in the inflow.

Other private capital flows will remain relatively unimportant in the 1990s, although they can be expected to rise from their present negligible levels. Some republics (particularly Costa Rica) may be able to issue bonds on the international market and may even attract a small amount of international capital into the stock market. Most of the increase, however, will come in the form of trade credits on a short-term basis.

Multilateral official capital flows, already of considerable importance in the 1980 s, should rise further in the next decade. Loans from the international multilateral agencies are essential for the task of reconstruction and the prospects are good for an increase from the Inter-American Development Bank 
(IDB) now that its capital base has been enlarged. There is also the prospect of an increase in grants from the European Community under the Cooperation Agreement. ${ }^{13}$ Although some bilateral official capital flows are set to decline in the 1990s for the reasons given above, there are also some donors (e.g. Japan) which can be expected to increase their Official Development Assistance (ODA) to the region. Furthermore, the US administration has restored its aid programme for Nicaragua, following the defeat of the Sandinistas in the 1990 elections, and Nicaragua is also attracting loans from multilateral agencies for the first time in nearly ten years. ${ }^{14}$ Taken together, official capital flows (multilateral and bilateral) should increase to fill the remaining gap in the current account deficit.

There is one other financial flow - capital flight - which is of great importance for the Central American balance of payments. The adoption of more and more stringent exchange controls in the 1980s has slowed down, but not eliminated, capital flight from Central America. That raises the question of whether and under what circumstances capital repatriation (i.e. the reversal of capital flight) might take place.

It would be a mistake to place too much emphasis on capital repatriation. The general consensus is that capital repatriation plays a following rather than leading role in economic recovery; thus, when a recovery is underway, some reversal of capital flight can be expected; but capital repatriation will not initiate the process of recovery. ${ }^{15}$

This conclusion is also likely to be correct for Central America. Thus, the new model of development should not rest on the assumption of capital repatriation. If the model is successful, some capital will return, but that is an added bonus which should not be built into the original calculations.

These highly speculative remarks about international financial flows lead to the conclusion that additional balance of payments support will be available for Central America in the 1990s. However, it is most unlikely to be on such a massive scale that the balance of payments ceases to be a constraint. Thus, policies to earn foreign exchange through export promotion are going to be very important and it is appropriate to turn attention to the international environment in which export promotion will take place in the 1990 s.

Central America is a region which has been, and remains, very open to international trade. This means the international environment affects the level and rate of change of the economy in numerous ways. These include the world market conditions for primary products, the opportunities for non-traditional exports, the international technology frontier and the transfer of technology, the 
role of multinational companies (MNEs) and trade in services.

Exports of primary products, for many decades the engine of growth in Central America, are sold at foreign prices determined in world markets; in addition, several key exports are subject to quotas agreed internationally. World demand is determined by the income elasticity together with price substitution effects. Thus, prices, quotas and elasticities (price and income) combine with world income to produce the global demand for each primary product and together with current market shares offer a first approximation to Central America's participation in the world market in the 1990s.

There is almost universal agreement that the outlook for the main primary products exported by Central America (with the exception of bananas) are not particularly favourable. It is still possible for primary product exports from the region to perform dynamically through an increase in world market share; indeed, the collapse of quotas for coffee was greeted by some producers as a golden opportunity to increase Central America's share of world coffee exports. ${ }^{16}$ However, even if supply constraints are ignored, this opportunity should not be exaggerated. Coffee quotas will eventually be reestablished and sales to non-quota countries may then be subject to greater restrictions. Only in the cases of Nicaragua and El Salvador, where the main task is to rebuild market share lost in the last ten years, can traditional primary products be expected to play a dynamic role.

There are, of course, a number of possibly favourable developments for traditional primary products. The failure to reach an agreement in the Uruguay Round of GATT negotiations at the end of 1990 was a severe setback, but the developed countries have returned to the negotiating table rather than risk the consequences of a major trade war. GATT, to which all five Central American republics either belong or have applied to join, should be strengthened as a result with improved mechanisms for eliminating arbitrary (and unilateral) import restrictions on agricultural and agro-industrial products. The Uruguay Round still holds out the prospect of a reduction in tariff and non-tariff barriers for tropical products in the main consuming countries. The formation of a Single Domestic Market in the European Community (EC) by 1993 means that the 12 EC countries must harmonise their treatment of imports (e.g. bananas) and that is likely to lead to a lowering of tariff and non-tariff barriers on average. ${ }^{17}$ The EC has also offered to extend to Central America the excise duty and tariff concessions offered in 1990 to the Andean countries for commodity exports. The Eastern European market is now opening up through trade liberalisation. One should not disparage these efforts, but their quantitative impact is likely to be small because the barriers are already low in most cases. 
The most realistic assumption, therefore, is for slow growth (one to two per cent per annum) in the volume of Central America's traditional primary product exports. Prices will no doubt also rise from their current low levels, but no major boost should be expected from improvements in the net barter terms of trade (NBTT) over the long-run. Indeed, taking the medium-term period up to 1993, the Sanford Commission worked on the assumption of a small deterioration in the NBTT and there is no compelling reason to quarrel with this even for the rest of the decade. ${ }^{18}$

In the case of non-traditional exports (agricultural and industrial) sold outside the region, world prices, quotas (in some cases such as textiles), price and income elasticities are also important, but market shares play a special role. This is because of the preferential schemes for all developing countries on the one hand (e.g. the Generalised System of Preferences - GSP) and on the other the special schemes (e.g. the Caribbean Basin Initiative - CBI - and the European Community's Cooperation Agreement) in which Central America can participate. The existence of these special schemes makes it easier to think of an increase in the region's market share over the next decade as feasible even if world market conditions are unfavourable.

An extension of the CBI has now been negotiated. Perhaps as important, an effort has been made to define its rules so that countervailing duties cannot be applied as arbitrarily as in the past (e.g. Costa Rica's cut flowers ${ }^{19}$ ). Nicaragua, following the election of President Violeta Chamorro and the defeat of the Sandinistas, has been made a beneficiary of the CBI and the US trade embargo against Nicaragua - in force since 1985 - has also been terminated.

The European Community, a wealthy market of over 300 million consumers, is still almost virgin territory for Central America's non-traditional exports. The Lomé Convention, signed between the EC and some 70 developing countries in Africa, the Caribbean and the Pacific, discriminates against Central America by offering special privileges to the Lomé signatories ${ }^{20}$, but the Cooperation Agreement signed with Central America in 1985 offers the prospect (so far largely unrealised) of eroding this discrimination through extending Lomé-type privileges to the region. As the Cooperation Agreement begins to function more effectively, there is a good chance that in the 1990s access to the EC for nontraditional exports will improve. This is the best way for Central America to combat the discrimination implied by Lomé since there is now no chance of the region being made a beneficiary of the Convention; the recent admission of the Dominican Republic and Haiti to Lomé was seen by the EC as a special case because of their geographical position and was explicitly not seen as a precedent for other small Latin American states. 
There is a widespread fear in many quarters that the formation of a Single Domestic Market (SDM) in the EC by 1993 will create a 'Fortress Europe' making it harder for third countries to export. These fears are greatly exaggerated. First, the legislation for the SDM requires the harmonisation of all tax and tariff rates for imports from third countries; in many cases of concern to Central America, these are already harmonised; where they are not, there is more likely to be a levelling down rather than a levelling up. Secondly, the formation of the SDM - indeed, its whole rationale - is expected to increase output and income per head. That will increase demand, particularly for those goods with high income elasticities.

The danger of a 'Fortress Europe' lies much more in the field of hightechnology goods and international services; this could well be a problem for developed country suppliers of the EC, such as Japan and the United States, but it is only of peripheral interest to Central America. In the kinds of goods and services that Central America might export to the EC in the 1990s, market access should improve after 1992. Thus, the special schemes for non-traditional exports could work to Central America's advantage in the 1990s. In addition, world market conditions generally for such products are not unfavourable. The long-run shift in world trade in favour of manufactured exports by developing countries is expected to continue and planned changes in the GSP should help a region such as Central America. Of course, problems will remain and the arbitrary application of non-tariff barriers and countervailing duties is bound to continue in some cases. However, there are no easy options for the region and the crucial question is the balance of benefits over costs. Looking at the whole picture, the market conditions for non-traditional exports do not look unpromising. There is also the chance that trade liberalisation policies in some developing countries (e.g. Mexico) will create a number of export opportunities for Central America which previously were ruled out by tariff and non-tariff barriers, and there remains the distant promise of a free trade agreement with Mexico and the United States as a consequence of President Bush's Enterprise for the Americas Initiative. ${ }^{21}$

Finally, there is the question of trade in services. Almost irrespective of the outcome of the Uruguay Round of negotiations on international trade in services, this branch of world commerce is set to grow in the 1990s in both absolute and relative terms. There is a widespread feeling that trade in services (estimated at 20 per cent of world commerce) will be dominated by MNEs, leaving Central America at a comparative disadvantage with a heavy deficit in its balance of payments service account. This is very misleading; services consist of many different activities, in at least one of which (tourism) Central America has already shown its potential. Yet there are many others where Central America has cost advantages through its wage scales and geographical 
position; this question will be explored further below (see Trade with the Rest of the World).

\section{Objectives of the Model}

There is already a great deal of discussion about instruments (e.g. tariff policy) in Central America. A long-run model, however, requires targets as well as instruments and the targets determine the choice of instruments. So far, there has been much less discussion of targets than instruments and this has not helped to promote consistent economic policy.

The first target must be the rapid growth of GDP per head. Whatever its deficiencies (and they are numerous), GDP per head will always be a rough proxy for living standards. In some countries (e.g. Costa Rica), rapid growth of GDP per head (two to three per cent per annum) throughout the next decade would take income per head to record levels; in others (e.g. Nicaragua), the best that can be hoped for is a recovery of income per head towards its level at the end of the 1970s.

It is difficult to imagine an increase in living standards without an increase in GDP per head. However, the converse is not true. It is possible to imagine an increase in GDP per head which does not lead to a generalised increase in living standards. Indeed, there are plenty of examples from Central America's recent past. Thus, a second target must be an improvement in the distribution of income through a reduction of poverty.

This target has acquired particular importance in Central America in the last decade. Income distribution, already highly unequal in the late 1970s, has become worse in the 1980 s and the incidence of poverty has accelerated. ${ }^{22}$ No doubt the debate on the definition of poverty will continue for many years, but the conclusion that poverty is now more widespread in Central America is inescapable.

A third target is self-sufficiency in basic grains at the regional level. This is a more controversial target. Some economists would argue that if a country can import rice or maize more cheaply than it can be produced locally, it should do so; the resources freed in this way can then be employed more productively elsewhere. This is a crucial policy issue, since it is well known that maize can be purchased more cheaply from Texas, for example, than it can be produced in Central America. ${ }^{23}$ 
There are good reasons for resisting this application of the law of comparative advantage. The economic case for specialisation rests on the assumption that the resources released can be reemployed in activities which contribute directly or indirectly to exports to pay for increased imports. If specialisation leads to factor unemployment, the case is undermined. In the Central American context, large-scale farms producing basic grains could probably be switched to export crops without too much difficulty, but the same is not true of small-scale farms and the latter dominate the production of basic grains.

The target of self-sufficiency in basic grains, however, can best be applied at the regional level. The goal is regional self-sufficiency leaving plenty of scope for free trade in basic grains within the Central American Common Market. Regional self-sufficiency gives large-scale farms the opportunity to profit from economies of scale, while offering some limited protection to smallscale farms.

The fourth target is an industrialisation project. Like self-sufficiency in basic grains, this is a controversial goal. Some would argue, for example, that if a country can achieve rising real GDP per head with a reduction in poverty without industrialisation, then there is no need for industrialisation; similarly, if real GDP and poverty targets are met through industrialisation, then that shows industry was a good instrument, but it does not make it a target.

The reasons for thinking of industrialisation in the Central American context as a target are complex. First, it is very difficult to imagine the first two targets being met in the long-run without an industrialisation project; secondly, industry has demonstrated throughout the world that it is a particularly powerful medium for promoting capital accumulation and the transfer of technology. To capitalise on these advantages, Central America has to insert itself into the world economy with an industrialisation project tailored to its dynamic comparative advantage. Market forces will go some of the way towards defining this project, but rates of return on capital are so strongly affected by the matrix of policy decisions that market forces cannot be defined as objective. They are themselves subject to policy decisions and it is better to recognise this explicitly; thus, policy decisions should be subordinate to the industrialisation project and not the other way round; this can only be achieved if the industrialisation project is a target.

An example from economic history will make this clearer. In the 19th century, Central America established its comparative advantage in coffee. Policy was not neutral, however, between coffee and other primary products; the Liberal reforms created a framework which favoured coffee in a hundred 
ways; the comparative advantage came from this framework ('the coffee project') and market forces did the rest; the rates of return on coffee, its value added and domestic currency price were the outcome of market forces, but those forces were shaped in large part by policies on land ownership, credit, interest rates, labour laws etc, all of which were subordinate to the goal of increasing coffee production.

An industrialisation project does not mean the promotion of any or all industrial activity for its own sake. That would be very wasteful. What is required is a project which complements the other targets and reaps the potential benefits of capital accumulation within a framework which promotes long-run (dynamic) comparative advantage. I shall return to this point below.

The fifth, and final, target is to narrow the technological gap between Central America and the rest of the world and to create a certain technological autonomy. Central America will, of course, remain a net importer of technology for many decades (if not for ever); however, the pace of global technical change has accelerated recently and promises to continue to do so in the 1990s. Countries or regions that must by and large import technology need an infrastructure that can adapt this technology to their own requirements; that means a more skilled labour force, a facility in design and engineering and a proper understanding of business administration and marketing. The construction of such a technological framework is the target for Central America in the 1990s.

\section{Constraints on the Model}

Short-run economic growth is usually determined by changes in demand. In the long-run, however, economic growth is determined by a number of constraints which limit the increase in supply. It is the purpose of this section to identify the main constraints which are likely to operate on the supply-side of the Central American economy in the 1990s.

The most important constraint is likely to be the balance of payments. A given growth of real income implies an even faster growth of imports in the Central American context, with foreign exchange needed for new capital equipment, raw materials, consumer goods, technology payments and services. The foreign exchange is provided by exports and net capital inflows, but it is safe to predict that in the 1990s the marginal efficiency of foreign exchange will remain high. Thus, increasing foreign exchange receipts to relax the balance of payments constraint and, ceteris paribus, permit a faster growth is 
a high priority.

The supply of energy is likely to be a further constraint on the long-run model. Forecasts of the energy balance suggest a gap between supply and demand in the 1990s even with fairly modest estimates of the growth of demand. ${ }^{24}$ Measures to increase supply (e.g. of hydroelectricity) are often very time-consuming as well as expensive. Furthermore, forecasts of supply do not take into account the possible decline due to environmental damage leading to lower water levels and silting in lakes.

If the forecast energy balances are taken literally, they imply a major reduction in the feasible long-run rate of growth in Central America. The energy balance is a very serious problem, but it is probably not the knife-edge problem implied by the forecasts. First, many businesses have built up their own generating capacity as a response to shortages and disruptions in public supply; this capacity very often does not show up in statistics, but can be used to supplement supply. Secondly, energy capacity can be increased quickly in the short-run through oil-burning plants; this adds further pressure to the balance of payments constraint, but it is a feasible (if costly) option.

These qualifications to the imbalance often forecast between energy supply and demand in the long-run do not imply that the sector can be neglected. On contrary, it is a matter of urgency to take steps now to increase supply in the medium- to long-term. It is encouraging to note the importance attached to this problem in the PEC. ${ }^{25}$

The third constraint on the model is the environment. It is now recognised that Central America's pre-1980 economic growth was achieved to some extent at the expense of the environment. The cost has been destruction of forests without replanting, pollution of lakes and rivers and coastlines and a decline in annual rainfalls in some parts of the region. The growth of the 1990s must take into account the impact of new projects on the environment through an accounting approach which puts a monetary cost on environmental damage. Projects should only be supported if the net discounted value of all benefits exceed the economic and environmental costs. ${ }^{26}$ In effect, the community should be asked to treat the environment like a capital good which is maintained in good order through an annual programme of repair and maintenance achieved through a depreciation charge on the national accounts.

Although the need for an ecological dimension to growth is widely acknowledged, it is not so easy to achieve. Societies, including those in Central America, have for centuries regarded the environment as a free good to be consumed at will. The adoption of an environmental constraint implies either 
a reduction of growth or an increase in cost; since Central America cannot afford to reduce growth, this means that costs will rise and that raises the question of who will pay. The beneficiaries of environmental improvement are not only national (in this case Central Americans), but also foreigners (pollution knows no frontiers). It is a problem which free markets are not well placed to solve, but one which will have to be addressed in Central America. ${ }^{27}$

The fourth constraint is likely to be provided by the conditionality of foreign lending. Conditionality is not usually mentioned in a list of constraints, but it has become very important in the Central American context and is likely to become more important in the 1990s. There are three reasons for this. First, I have argued above for an increase in foreign lending to the region and there is a loose connection between the extent of conditionality and the volume of borrowing; secondly, as more normal conditions return to Central America, lenders will be more inclined to attach conditions to loans that increase the chance of repayment; thirdly, the additional lending to the region will fall disproportionately on official multilateral sources, which have shown themselves to be the keenest on applying conditions. ${ }^{28}$

Everyone accepts the need for some kind of conditionality, but there comes a point where conditionality represents an unacceptable restriction on national sovereignty. This is a problem not only for Central America, but also for many other developing countries. However, it is likely to be a particularly sensitive problem for Central America as there will be so many donors in the 1990s, each with different priorities and some with different ideologies.

There is no easy answer to this problem, but one golden rule applies. If a country receives a loan to support the balance of payments, it is appropriate that conditions are attached which increase the likelihood of an improvement in the balance of payments; what is not appropriate is the attachment of conditions which the donor would like to see adopted, but which are largely irrelevant as far as the balance of payments are concerned. If donors and recipients stuck to this basic rule, not all the problems of conditionality would be solved but it would remove some of the ill-feeling.

A fifth constraint on the model is likely to come from the financial system. There can be no economic development in Central America without an increase in the rate of investment (expressed as a percentage of GDP). Part of the increase can be paid for by an increase in foreign borrowing; furthermore, the reactivation of the economy will permit a recovery in reinvested profits. Nevertheless, part of the increase will have to come from an increase in domestic savings. ${ }^{29}$ 
This creates two special problems. First, failure to improve the financial system in a manner that increases voluntary savings runs the risk of encouraging forced savings through an acceleration of inflation. This has been particularly evident in Nicaragua where the inflation tax in the 1980s became one of the main sources of government revenue. From the experience of the last decade, we can see that the extent of poverty is very sensitive to the rate of inflation; the poor in Central America suffer most from an acceleration of inflation and an increase in the 1990s is not acceptable. Secondly, the traditional mechanism for increasing domestic savings - an increase in income inequality - is also not acceptable in Central America. New sources must be tapped through a variety of new instruments - including the capturing of remittances by the banking system.

The final constraint on the model is the educational system. The training of Central America's human resources was far from adequate at the end of the 1970 s, with the notable exception of Costa Rica. In the 1980s, the educational system has declined dramatically in quality as the economic crisis took its toll. The economic model for the 1990s and beyond requires a more skilled labour force with greater flexibility, greater numeracy and - above all - greater literacy. The restoration, improvement and extension of the educational system is a matter of pressing concern. ${ }^{30}$

\section{A Counterfactual Experiment}

A long-run model for Central America must be designed in such a way as to take advantage of research already completed, the experience of the past and the ideas of other interested groups. There is a danger in this approach, however, because the proposed model may be unduly influenced by previous work; the purpose of the model is to find the instruments which can satisfy the goals in a manner consistent with the constraints. Other work on long-run development in Central America may start from different goals to those outlined above or may be bound by different constraints.

In this section, therefore, a counterfactual experiment is adopted. In this experiment, there are assumed to be no previously existing models; there are no international agencies such as the World Bank or the IMF. The purpose of the experiment is to explore the logical characteristics of a long-run model which satisfies the goals and constraints outlined above.

For any given Central American country, there are three sources of demand: internal (i.e. national), regional (i.e. the rest of Central America) and foreign 
(i.e. the rest of the world). The first question, therefore, refers to the priority to be given to each source of demand.

A model which began with an expansion of the internal market (e.g. through income redistribution) might appear to meet many of the goals, but would rapidly violate the balance of payments constraint. In the context of the 1990s, allowing for the expected capital flows, a model which began with an increase in internal demand would soon fail. The direct and indirect import content of the consumption pattern of the lower income groups, let alone the higher income groups, is too high to permit a significant expansion, ceteris paribus, of internal demand.

A model which gave priority to regional demand would also violate the balance of payments constraint, although for different reasons. For the region as a whole, intraregional exports and imports are equal. However, the extraregional imports associated with an expansion of intraregional trade are very high; at the very least, the coefficient is 0.3 and this could rise to 0.5 when indirect capital costs, royalty payments and profit remittances are taken into account. ${ }^{31}$ Of course, intraregional trade expansion is also saving foreign exchange through regional import substitution. However, the expansion of intraregional trade stimulates the non-trade sector, encouraging further imports directly and indirectly, and may undermine extraregional export earnings through changes in relative prices. Thus, a model which relied, ceteris paribus, on an expansion of regional demand would also soon violate the balance of payments constraint.

Internal and regional demand are, to some extent, under the control of the authorities. Foreign demand is not. Thus, a model giving priority to foreign demand is in fact a model giving priority to the increase of regional supply for foreign markets. Clearly, such a model would not violate the balance of payments constraint; on the contrary, the increase in export earnings - net of additional imports required directly and indirectly by export expansion - will ease the balance of payments constraint.

However, a policy of giving priority to foreign demand will, ceteris paribus, face other problems. There is a very real danger, in the Central American context, that the instruments used to promote extraregional exports, e.g. unilateral tariff reductions, will discriminate against intraregional trade. Since intraregional trade is dominated by manufactured goods, the policy of promoting extraregional exports may undermine the goal of an industrialisation project. If the new exports to the rest of the world are industrial, this might not matter; if, however, they are agricultural products or the products of maquiladoras $^{32}$, this could leave the goal of an industrialisation project 
seriously weakened.

It is not only regional demand that may be undermined by a policy of giving priority to extraregional exports. The need to shift resources towards the export sector and to provide an attractive rate of return for domestic and foreign capital can undermine the internal market through a growing concentration of income and wealth. This violates the goal of improving income distribution through a reduction of poverty.

One would have to be very naive not to recognise that these conflicts between foreign demand on the one hand and regional/national demand on the other can occur in practice. In Central America, for example, export promotion is increasingly being pursued through a policy of unilateral tariff reductions, in violation of regional treaties, which has turned CACM from a Customs Union into a Free Trade Zone. ${ }^{33}$ Similarly, Costa Rica's spectacular success with non-traditional exports has been achieved, it is generally agreed, through a sharp concentration of income. ${ }^{34}$

It seems, therefore, that the long-run model faces an awkward choice; the logic of the Central American economies, in particular the balance of payments constraint, suggests giving priority to foreign demand, but giving priority to foreign demand appears to run the risk of violating some of the objectives set out above.

Faced with this choice, some modellers appear to be willing to abandon all goals other than maximisation of the rate of growth of real GDP per head; ${ }^{35}$ this, at least, is consistent, but it is also defeatist. Furthermore, the objectives outlined above are not optional extras; they are essential ingredients for Central America's long-run economic development.

Fortunately, it is possible to resolve this dilemma. Priority needs to be given to foreign demand in such a way that it is complementary with the expansion of regional demand and the internal market. This is difficult, but - as we shall see - not impossible. At present, the outward-looking policies adopted to promote trade liberalisation far too often have undermined rather than complemented the two other sources of demand.

Thus, the issue for Central America is not whether or not to have an apertura through outward-looking trade policies. The issue is what kind of apertura and, in particular, the need to select instruments in such a way that they do not undermine the other sources of demand nor violate the goals of the long-run model. 

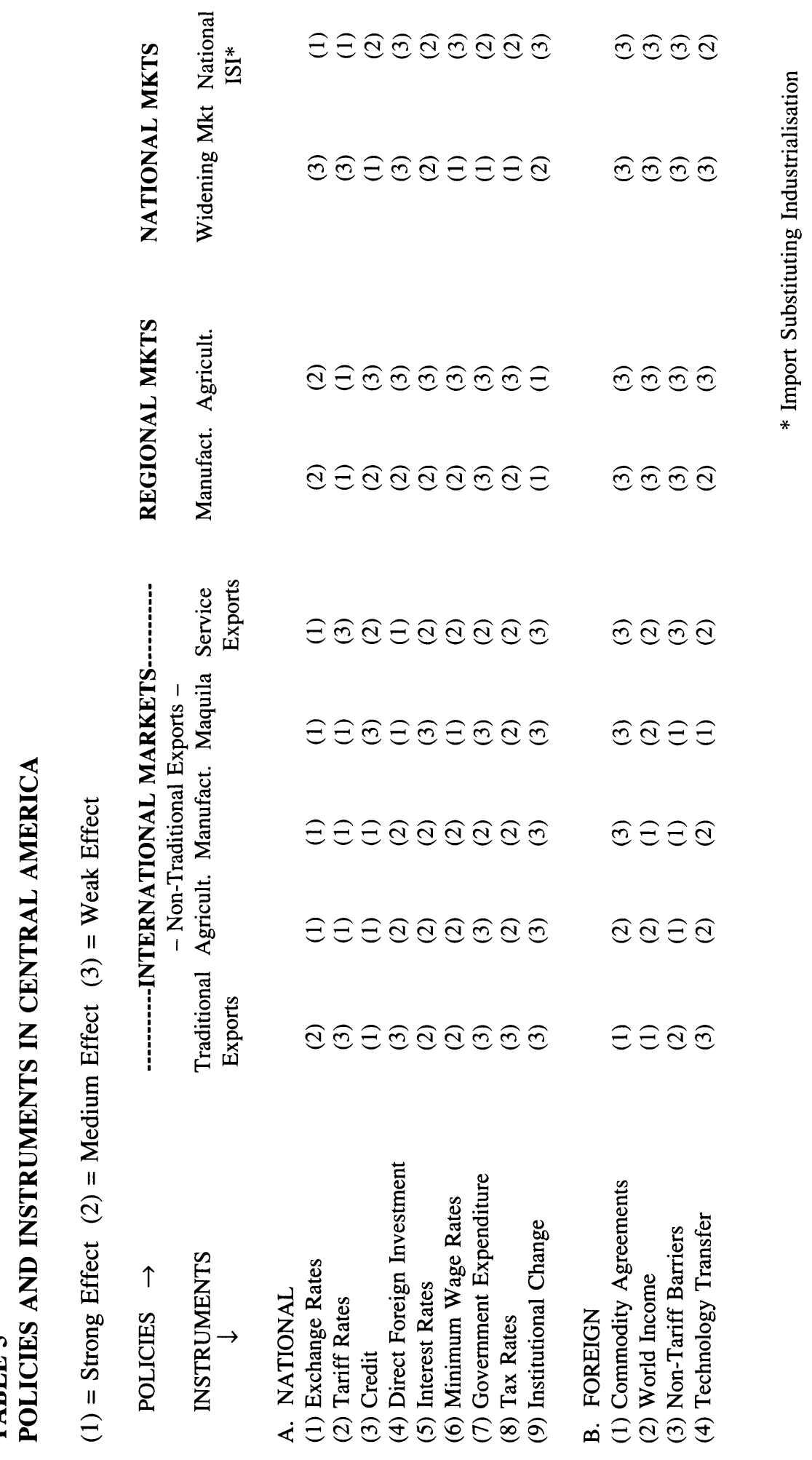


\section{Policies and Instruments}

There is a frequent, albeit understandable, tendency in economics to use the words 'policies' and 'instruments' interchangeably. For many purposes, there is no need to distinguish the two, but it is necessary in this context. Policies refer to strategies which the authorities try to achieve through the manipulation of instruments; thus, for example, the authorities change the exchange rate (an instrument) in the hope that this will promote non-traditional exports (a policy). While the authorities undoubtedly control the instruments, there is much less control over the policies.

In this section, the instruments relevant for the policies required by a longrun model for Central America are outlined. This is done by means of a matrix (see Table 5) with policies in the columns and instruments in the row. Each instrument can then be assessed in terms of its likely impact on each policy; a grading system is used from three (a weak effect) to one ( a strong effect). Clearly, these judgements are subjective, but they are not arbitrary. The grading system is intended to reflect the conclusions of the economics profession on the efficacy of various instruments in the Central American context.

The first five columns refer to policies for increasing exports to the rest of the world. The first column refers to traditional exports, which in the Central American context means the 'famous five' (coffee, bananas, cotton, sugar and beef); some non-traditional exports (e.g. cardamom from Guatemala) are now showing many characteristics of traditional exports, but the distinction is so well-established in the region that it is preferable not to change the list of traditional exports.

The next three columns refer to non-traditional exports of goods to the rest of the world (ROW). The three kinds of goods are agricultural, manufactured (including agro-industrial) and the products of maquiladoras. All too often no distinction is made between these three kinds of non-traditional exports, although each has very different implications for the goals of the long-run model and each is likely to affect the constraints in different ways.

The fifth column refers to exports of services to ROW. Although almost everyone acknowledges the promising future which Central American tourism (a service to ROW) offers in the long-run, many are inclined to argue that the comparative advantage in service exports will remain with the advanced industrial countries in the 1990s. At the global level, it is no doubt true that a shift is taking place in the international division of labour which favours exports of manufactured goods by developing countries and of services by 
developed countries. However, at the regional level it is possible to identify many service exports (in addition to tourism) which could profitably be exploited by Central America. This point will be explored in the next section.

Columns six and seven of Table 5 refer to the regional market (CACM). The first of the two columns refers to a policy of increased trade in manufactured goods; this includes the well-known policy of regional import-substituting industrialisation (ISI), so successful in the 1960s, but it also includes any policy for promoting intraregional trade in manufactured goods, including agroindustrial products. The second of the two columns refers to intraregional trade in agricultural products; this includes, for example, trade in basic grains as well as trade in raw materials.

The final two columns refer to policies designed to widen the internal market. The first refers to policies to widen the market without national import substitution (e.g. poverty reduction through rural public works), while the second refers to policies to widen the internal market through import substitution at the national level.

The rows of Table 5 contain details on the instruments available. In the interests of completeness, a distinction must be made between those instruments controlled by the domestic or regional authorities and those controlled by the rest of the world. The latter list, of course, is far from complete, but a number of instruments are mentioned which have an important bearing on the policies in the columns and which are not controlled by authorities in Central America. Examples are the quotas for traditional exports to ROW, non-tariff barriers applied to non-traditional exports by advanced industrial countries and the transfer of international technology.

The other instruments are all assumed to be subject to control by the domestic or regional authorities. In some cases this is uncontroversial (e.g. nominal exchange rates and minimum wage rates). In other cases (e.g. Direct Foreign Investment - DFI), it is only partly true since the actual flow of DFI depends on a host of factors only some of which are controlled by the authorities. Furthermore, many of the instruments (e.g. tariffs) are increasingly subject to conditions agreed with international agencies and therefore not entirely in the hands of governments. Nevertheless, the decisions of the authorities have an important bearing on each of the instruments listed in the first nine rows of the table.

The instruments, in turn, affect the policies and their effect varies from weak to strong. For example, in the case of the exchange rate, a real depreciation is likely to have a strong effect (1) on non-traditional exports to ROW and on 
national ISI; it is expected to have a moderate effect (2) on traditional exports and on exports to the regional market, and only a weak effect (3) on widening the internal market through means other than national ISI. On the other hand, in the case of tariffs, a reduction in nominal tariff rates is expected to have a weak effect (3) on traditional exports, service exports and widening of the national market and a strong effect (1) on all other policies.

The three 'financial' instruments (credit, DFI and interest rates) are assumed to have a variety of impacts on the different policies. An increase in credit, for example, is expected to have a strong effect (1) on the first three policies and on widening the national market, but only a weak effect (3) on exports of maquiladoras. By contrast, an increased flow of DFI is likely to have a strong effect (1) on exports from maquiladoras and on service exports. The interest rate instrument is expected to have a moderate effect (2) in all cases except maquila and regional exports of agricultural goods, where it is assumed to have a weak effect (3).

The three 'fiscal' instruments (minimum wage rate, government expenditure and tax rates) are all assumed to have strong effects on widening the national market; the minimum wage rate is also expected to have a strong effect (1) on maquiladoras, a weak effect (3) on regional ISI and a moderate effect (2) in most other cases. Finally, institutional change is seen as particularly important in the case of the two regional market policies, but of less importance in respect of all other policies.

The table also makes clear the impact of the foreign-controlled instruments on the policies. For example, non-tariff barriers erected by advanced industrial countries are expected to have a strong effect on the three kinds of nontraditional exports to ROW, a moderate effect on traditional exports and a weak effect elsewhere (including exports of services).

Looking down the columns of Table 5 gives a first idea of what is required to promote a particular policy. In some cases this is clearly more difficult than in others; for example, in the case of traditional exports, there are only three instruments identified with strong effects and two are controlled by foreigners. On the other hand, in the case of the maquila industry, there are five instruments identified with strong effects and four are assumed to be subject to domestic or regional control.

We can now turn to possible conflicts between instruments and policies. For example, in the case of tariff reductions, there will be a strong effect on nontraditional exports to the rest of the world and on regional exports, but the effects will be in opposite directions. In the first case, exports will be promoted 
and in the second they will be undermined. Thus, the choice of instruments has to be made in terms of the chosen mix of policies and not just in terms of a single policy. Similarly, an increase in minimum wage rates will widen the national market, but will undermine exports from maquiladoras.

In formal modelling terms, the problem can be described as follows: there is an objective function containing five dimensions (see the objectives above), which must be maximised subject to the constraints. This must be done by selecting and setting the instruments described in this section in an optimal fashion, where 'optimal' simply means that the combination of instruments achieves the highest value of the objective function consistent with the constraints.

This is a very familiar problem in linear - or quadratic - programming. The problems associated with this kind of approach, however, are in practice formidable. In the remaining sections, therefore, the kind of approach which should guide policy-makers in trying to resolve this problem in practice will be outlined. The problem remains the same, however, since the focus is on trying to find instruments which can maximise the goals of the model without violating the constraints. The approach here is qualitative, therefore, rather than quantitative, although in principle the two approaches should give the same results.

\section{Trade with the Rest of the World}

Trade liberalisation in Central America requires apertura policies which complement, rather than undermine, the regional and domestic markets. Given the obstacles facing traditional exports, these apertura policies are primarily directed at non-traditional exports of goods and services. This does not mean that traditional exports are expected to decline in absolute terms - indeed, a modest increase in value and volume is possible - but it does mean that they are expected to decline in relative terms as a proportion of total exports and as a proportion of GDP.

There is no doubt that export promotion requires apertura policies, but there are still many ways in which apertura policies can combine to promote exports and some of these ways are more likely than others to be consistent with the goals of the long-run model. As a first step, it is necessary to distinguish between apertura policies which are rapid and those which are gradual; it is also necessary to distinguish between those which are indiscriminate and those which are selective. 
This produces a small $2 \times 2$ matrix with four possibilities:-

\begin{tabular}{||l|c|c||}
\hline $\begin{array}{l}\text { TRADE } \\
\text { LIBERALISATION } \\
\text { OPTIONS }\end{array}$ & INDISCRIMINATE & SELECTIVE \\
\hline RAPID & $(1)$ & $(3)$ \\
\hline GRADUAL & $(2)$ & $(4)$ \\
\hline
\end{tabular}

The first option (1), rapid and indiscriminate apertura policies, implies a swift reduction of tariff rates, a flexible exchange rate and a liberalisation of interest rates; the free market is left to determine the allocation of resources and comparative advantage is 'revealed' by those activities which do best under the new rules of the game; comparative disadvantage, by contrast, is revealed by those activities which are forced to close. The second option (2) is similar to the first, except that tariff reductions are introduced gradually and other instruments (e.g. credit controls) which have influenced the allocation of resources are phased out slowly.

The third option (3), rapid and selective apertura policies, assumes that the authorities do not wish to promote all export activities equally. Thus, the instruments are changed rapidly, but in such a way as to favour certain sectors more than others. The free market is now not the only determinant of comparative advantage and the authorities are forced to adopt a position on the difficult question of where the country's long-run comparative advantage is thought to lie. The fourth option (4) is similar to the third, except that the instruments of trade liberalisation are assumed to be introduced gradually rather than rapidly.

The first question to be answered is whether, in the Central American context, apertura policies should be rapid or gradual. A rapid apertura has the advantage that interested parties do not have time to form pressure groups to distort the liberalisation process; it is a form of shock treatment which under the right conditions can achieve a very sharp increase in efficiency and productivity in certain activities. However, these conditions are unlikely to be found in Central America. In particular, a rapid apertura without a prior process of industrial modernisation (reconversión industrial) is likely to lead to factory closures and a decline in the industrial base. Indeed, it is not difficult to imagine many industrialists responding to a rapid apertura by converting 
their factories into import businesses.

Some activities would undoubtedly prosper even in Central America from a rapid apertura. The combination of lower tariffs on imported inputs coupled with a competitive exchange rate works to the advantage of non-traditional agricultural exports, since they are not at risk from competing imports and there are few barriers to entry for new firms. The same is true, to a lesser extent, of maquiladoras, where barriers to entry - at least for domestic firms - tend to be higher because of the capital requirements and the need for information on export markets.

However, an apertura that is gradual would still favour these two groups without subjecting the weak industrial base to the same pressures. Given the need for reconversión industrial ${ }^{36}$, for training the labour force in new skills and for learning about foreign markets, the gradual introduction of liberalisation policies is likely to be optimal in Central America. That means phasing in over a number of years the tariff reductions and exchange rate changes etc. that are needed to implement an apertura policy. Of course, even a gradual apertura cannot safeguard all the firms in the industrial base and the most inefficient will be forced to close, but some firms which would otherwise be forced out of business will be given the chance to become internationally competitive.

The second question is whether the apertura should be indiscriminate or selective. An indiscriminate apertura has the advantage that the authorities do not have to become involved in picking winners. The free market decides and long-run comparative advantage is determined by short-run response to the new vector of prices.

Indiscriminate apertura policies, however, suffer from a number of disadvantages. There is no guarantee that the new exports will be consistent with the goals of the long-run model; for example, none of the products need be industrial and they could all come from activities requiring very little unskilled labour; the non-traditional export sector could still be very dynamic, but it could be moving the economy in a direction which runs counter to the stated goals.

Another problem has to do with short-run versus long-run comparative advantage. It may be in a country's short-term interests, for example, to welcome new exports based on cheap labour taking advantage of some international trade concession of a temporary nature. Clearly, this is a very risky strategy in the long-run, since by definition the trade concession is temporary and there is always some other country which can provide even cheaper labour. Also, a cheap labour strategy implies a policy of exchange rate 
devaluation which is likely to run counter to efforts to improve income distribution in the longer term.

A third problem, very relevant in Central America, is the implications of an indiscriminate apertura policy for social infrastructure. Promotion of exports requires cooperation between the private and public sectors, with the latter providing the social infrastructure to remove various supply-side bottlenecks. An indiscriminate apertura can produce an export list. which requires public expenditure far in excess of what is required by a more selective list. A list of 100 items of $\$ 1$ million each has very different resource implications to a list of two items of $\$ 50$ million each.

It is worth remembering that each of the five main traditional exports in Central America was introduced in a selective fashion. The incentives for coffee producers in the 19th century (e.g. free land and coffee trees) were not available for other exporters $;^{37}$ the concessions offered to the fruit companies at the turn of the century were only available for bananas; the introduction of cotton in the 1940s was made possible by public investments and credit policies designed to favour its export and similar support was provided for sugar and beef. A policy of selective apertura is therefore more consistent with Central American history and likely to avoid the disadvantages of an indiscriminate apertura.

A selective apertura need not mean discriminatory tariffs. On the contrary, the construction of 'made to measure' tariffs is extremely difficult and fraught with problems. It is preferable that the element of selectivity is introduced through a coherent credit, interest rate, exchange rate and DFI policy which works in favour of the selected activities. It is, therefore, a policy in favour of particular (selected) activities rather than a policy discriminating against other (non-selected) activities.

A selective apertura policy does require the selection of preferred activities and this should clearly be done in such a way as to be consistent with the goals of the long-run model. This is most likely to be achieved through activities in which the foreign market is complementary to the regional or domestic market. A good example is provided by agroindustries. Exports of agroindustrial products use intensively raw materials which are grown in the region; these raw materials are, or can be, produced by small-scale farmers or agricultural cooperatives in a way that makes a significant impact on the reduction of poverty; often the raw materials, and their processing, require the adaptation of foreign technology in a way which obliges firms to establish a limited research and development capability. Agroindustrial products are potentially a very lucrative market. Income elasticities for many such products are high and the 
new products are often not at risk from synthetic substitutes because the demand is for natural resource-based products.

The long-run comparative advantage enjoyed by Central America in agroindustries is derived primarily from its natural resource base. For some countries (i.e. Costa Rica), it is also possible to select sectors for dynamic comparative advantage based on skill-intensive manufactured products; this advantage is derived from an educated labour force in which skills are rewarded in dollar terms at a fraction of their cost in advanced countries. These manufactured goods offer the prospect of significant backward and forward linkages, need a certain firm-level technological expertise and contribute to a widening of the internal market through the payment of wages and salaries which are high by local standards.

Apertura policies which are gradual and selective - option (4) above - can also be applied to the service sector. The division of labour in international services is subject to many forces, but one is the quality and price of labour inputs domestically. The advance of technology has made possible trade in many services which were previously considered non-traded. A good example is the repair and maintenance of jet aircraft, which need not be carried out in the country or countries where the jets operate. Another example is data processing, which can be carried out far from the country to which the data refer.

Central America also has yet to reap to the full the advantages of its geographic location between the Pacific and the Atlantic. The restoration of more normal conditions in Central America in the 1990s will allow decisions about a second inter-oceanic canal or a trans-isthmian oil pipeline to be taken in a calmer environment. Similarly Central America remains a potential bridgehead for transhipment of goods from South America to North America and its position on the edge of the Pacific rim should also not be overlooked. The scope for increasing exports of services, therefore, remains considerable.

\section{Regional Cooperation}

Regional cooperation ( $\mathrm{RC}$ ) includes the special case of regional integration (RI), but RC is broader than RI. It is important to remember this, since the five Central American republics do have an opportunity - as we shall see - to pursue cooperation in areas other than a formal customs union. 


\section{TABLE 6}

INTRAREGIONAL IMPORTS IN CENTRAL AMERICA (\$ MILLION)

$\begin{array}{lllllll} & \begin{array}{l}\text { Costa } \\ \text { Rica }\end{array} & \begin{array}{l}\text { El } \\ \text { Salvador }\end{array} & \begin{array}{l}\text { Guate }- \\ \text { mala }\end{array} & \begin{array}{l}\text { Hond- } \\ \text { uras }\end{array} & \begin{array}{l}\text { Nicar- } \\ \text { agua }\end{array} & \text { Total } \\ \mathbf{1 9 8 1} & 152.3 & 304.8 & 186.4 & 118.3 & 210.6 & 972.4 \\ \mathbf{1 9 8 2} & 112.3 & 260.8 & 219.9 & 86.8 & 108.6 & 788.4 \\ \mathbf{1 9 8 3} & 120.1 & 233.1 & 229.3 & 104.7 & 121.1 & 808.3 \\ \mathbf{1 9 8 4} & 114.8 & 251.4 & 186.5 & 99.0 & 70.8 & 722.5 \\ \mathbf{1 9 8 5} & 92.6 & 216.7 & 99.4 & 75.0 & 64.0 & 547.7 \\ \mathbf{1 9 8 6} & 106.2 & 161.0 & 102.4 & 58.1 & 42.6 & 470.3 \\ \mathbf{1 9 8 7} & 116.8 & 181.3 & 132.0 & 60.3 & 37.7 & 528.1 \\ \mathbf{1 9 8 8} & 119.3 & 197.5 & 148.4 & 63.0 & 36.8 & 565.0 \\ \mathbf{1 9 8 9} & 137.6 & 200.9 & 166.9 & 62.7 & 31.2 & 599.3 \\ \mathbf{1 9 9 0} & 145.5 & 213.7 & 143.6 & 84.8 & 51.3 & 638.9\end{array}$

* Preliminary results

Source: Consejo Monetario Centroamericano, Boletín Estadístico 1990, San José, 1991, Cuadro No. 6

It is true, however, that RI remains the most important feature of $\mathrm{RC}$ in Central America. Furthermore, after almost a decade of decline, there are signs that the Central American Common Market (CACM) has turned a corner (see Table 6). The value of officially recorded intraregional trade has been rising modestly since $1986,{ }^{38}$ Honduras has announced its intention of rejoining CACM in the near future and the Cámara de Compensación looks set to increase its role in the multilateral payments system ${ }^{39}$ as a result of the recent agreement between the Consejo Monetario Centroamericano and the European Community. ${ }^{40}$

The future of the Central American Common Market, therefore, and indeed the whole project in favour of regional economic integration, is at present delicately poised. The decline of CACM in the 1980 s, the most visible evidence 
of which has been the collapse of intraregional trade, was at first attributable to 'objective' forces such as the debt crisis; other 'subjective' forces, however, have also been involved which in some respects pose an even greater threat to the future of CACM. The forces in favour of integration were, until recently, very weak, but they have now become stronger and are being articulated more coherently.

The CACM should be an essential part of the industrialisation process in Central America and should be seen as a complement to non-traditional exports to the rest of the world rather than as an alternative. The revival of the CACM, however, is by no means assured; not only are the forces in favour of disintegration very powerful, but there are also a series of barriers which have to be removed before the CACM can function efficiently. Merely removing the barriers blocking increased economic integration is not enough. A revival of the CACM along the lines followed in the 1960s is not sufficient; that model of economic integration is now redundant and what is required is a new kind of integration complementary to export promotion to the rest of the world.

The economic crisis in Central America, which started for most republics at the beginning of the 1980s, was sparked off by the decline in the external terms of trade and the advent of the debt crisis. The subsequent balance of payments problems provoked a shortage of foreign exchange and restrictions on imports (including imports from the rest of Central America), thus confirming once again that extraregional and intraregional trade are complementary. The economic crisis also produced a sharp fall in real consumption per head so that demand for imported consumer goods from the rest of Central America declined.

The balance of payments crisis had two further negative effects on CACM trade. First, it made it impossible for 'deficit' countries (particularly Nicaragua) to service their debts contracted with 'surplus' countries. ${ }^{41}$ This meant that those republics running a trade surplus on bilateral intraregional trade within the CACM had no incentive to increase exports and, indeed, had an incentive to reduce them. Secondly, any potential expansion of CACM trade was weakened by the knowledge that for the region as a whole an increase in trade requires an increase in imported inputs for which foreign credits were unlikely to be available. ${ }^{42}$ Thirdly, balance of payments pressures brought an end to the exchange rate stability of the 1950s, 1960s and 1970s which had effectively achieved monetary union in Central America on a dollar standard. In the 1980s, exchange rate volatility increased uncertainty and the currency risks associated with CACM trade, while countries with overvalued exchange rates were unable to provide sufficient incentives for CACM exports. 
During the 1980s, a new economic model for Central America began to be promoted. The new model stresses non-traditional exports to the rest of the world and it has been pursued most energetically and successfully in Costa Rica. The new model leaves little space for CACM for several reasons. First, exports are sold outside the region and imported inputs are typically not obtained from CACM. Secondly, the model requires a reduction in anti-export bias; one of the most important causes of bias is the tariff on imported inputs. Any reduction, however, in nominal protection is likely to weaken the incentives in favour of CACM trade.

The new model has been promoted by several international agencies, notably the World Bank and USAID. The leverage of these agencies is considerable; the World Bank, for example, in its current Structural Adjustment Lending (SAL) programme for Costa Rica has insisted on a reduction in nominal tariffs and is trying to achieve the same in negotiations with Guatemala. These tariffs, however, are part of the Common External Tariff (CET) of the CACM, which was revised as recently as 1986 . Any unilateral reduction in these tariffs means that the CACM ceases to be a Customs Union and becomes, at best, a Free Trade Area. This is a momentous step which is being thrust upon Central America by the World Bank without sufficient public awareness of what is going on. ${ }^{43}$

There have also been political factors at work in the decline of the CACM. The anti-Marxist forces in Central America together with the Reagan administration feared that a recovery of the CACM would indirectly benefit the Sandinistas in Nicaragua. US funds in support of regional institutions, such as SIECA, were therefore withdrawn and questions have been raised about the competence of the Central American Bank for Economic Integration (BCIE). The advent of the Bush administration and the electoral defeat of the Sandinistas has led to a more flexible policy towards Central America. This does not mean, however, that US funds are again being used to promote regional integration. On the contrary, the dominant line in Washington is that regional economic integration is largely irrelevant in Central America's struggle for economic reconstruction and recovery. ${ }^{44}$

The forces favouring a revival of CACM have been motivated by both political and economic considerations. On the economic side, there are still many firms (particularly in Guatemala) which depend heavily on exports to CACM. ${ }^{45}$ There is also a feeling among many economists inside and outside Central America that a model of industrialisation based only on the national market and non-traditional exports to the rest of the world is likely to be very fragile and will not offer long-term advantages for the development of new industries with good growth prospects. 
On the political side, it has been widely recognised that economic integration is needed to underpin the Esquipulas peace process ${ }^{46}$ - in other words, there can be no lasting peace without integration and integration requires some sort of economic integration. This line of thinking has influenced the European Commission (EC) and is reflected in the Cooperation Agreement signed between the EC and Central America; it also influenced the Sanford Commission which presented its report in February 1989 and which came out strongly in favour of regional economic integration as part of a reconstruction package in Central America. ${ }^{47}$

Non-traditional exports to the rest of the world are a necessary feature of the new model of development for Central America. Their promotion requires a revision of many aspects of economic policy in order to remove or eliminate anti-export bias; non-traditional exports, however, are not sufficient in themselves to rescue Central America from its current economic crisis. The net earnings of foreign exchange are much less impressive than the gross earnings, the new products are often particularly sensitive to the threat of protection in developed country markets, they suffer from weak backward and forward linkages and they offer only limited scope for developing technological skills. $^{48}$

Policies designed to promote non-traditional exports should, however, be tailored to avoid undermining regional economic integration. That means resisting the World Bank's demands for unilateral reduction in tariffs, although a further multilateral reduction in the CET would be acceptable. The maintenance of a Customs Union is essential for the viability of regional integration in Central America; the creation of a Free Trade Zone through unilateral tariff reductions would make it much more difficult to remove the non-tariff barriers which currently impede intraregional trade. ${ }^{49}$

Merely resisting policies which threaten to undermine CACM is not sufficient. Trade within CACM has started to expand again in the last five years (see Table 6), as all the republics except Nicaragua return to modest rates of GDP growth; the expansion of trade, however, has been far from spectacular and many barriers to future growth still remain. The Derecho de Importación Centroamérica (DICA) scheme, designed to make it possible to pay for intraregional imports in soft currencies, did not function effectively ${ }^{50}$ and a high proportion of CACM trade is believed now to take place with payment in kind through barter. ${ }^{51}$ The intra-CACM debts, built up in particular by Honduras and Nicaragua, remain and act as a brake on future CACM expansion. There is still very little finance available for imported inputs required by the expansion of CACM trade and the new mechanisms to prevent the problem of structural deficits arising again in intraregional trade in the 
future have yet to be properly tested.

Given its commitment in favour of regional integration, expressed through the Cooperation Agreement, the European Commission has an important role to play. The agreement signed in September 1989 between the EC and the Consejo Monetario Centroamericano to reactivate the Cámara de Compensación is therefore particularly welcome. ${ }^{52}$ It is still too early to evaluate the success of the agreement, but the willingness of the EC to use multilateral funds in effect for balance of payments support is an important departure from its previous insistence on only project or programme lending. ${ }^{53}$

The agreement should lead to a big increase in the proportion of intraregional trade passing through the Cámara de Compensación. At the same time, the greater security of payment for exports should help to produce an increase in total intraregional trade. What is not clear is whether the benefits of this increase will be equally distributed among the countries of Central America. If the benefits are monopolised by the surplus countries (Guatemala and Costa Rica), the prospects for an increase in regional integration will again be in jeopardy.

Particular importance therefore attaches to the case of Nicaragua, the republic with the greatest problems of structural deficit within CACM trade and the largest accumulation of intraregional debts. The new agreement will certainly promote Nicaraguan imports from CACM, but without a corresponding increase in Nicaraguan exports to CACM the fund created by the EC for financing intraregional trade will soon be exhausted and the agreement will lapse.

The defence mechanisms within the agreement are designed to guard against such a possibility and an additional fund has been set up to help the weakest countries (Nicaragua and Honduras). This is a sensible precaution, but in itself it does not guarantee additional exports from Nicaragua. However, the draconian stabilisation programme in Nicaragua has so depressed the internal market that firms in the private sector are now looking towards exports. With many enterprises still unable to compete in the world market, the regional market is a realistic alternative now that Nicaragua has a competitive exchange rate and the private sector does not have to surrender the proceeds of export sales to the Central Bank. Exports to CACM have begun to increase and this must improve the prospects for the success of the agreement between the EC and the Consejo Monetario.

Thus, there are prospects for an increase in intraregional trade, but this still leaves many problems unresolved. The future success of regional integration 
in Central America depends on the introduction of changes which make integration consistent with outward-looking policies and which avoid the errors of the past; these included inefficient import-substituting industrialisation (ISI), a concentration of income and wealth which limited the effective market for many ISI goods to the top three deciles of income earners and an unequal distribution of the net gains from integration among the five countries.

The need to avoid inefficient ISI in the future requires lower tariffs. High tariffs imply not only high nominal rates of protection, but also for many industries even higher effective rates of protection. There is circumstantial evidence that, even after the regional tariff revision adopted at the end of 1985, there is 'water' in the tariff on many goods so that a reduction in tariffs is both desirable and feasible. ${ }^{54}$

However, many of the advantages of RI will be lost if this reduction in tariffs is carried out unilaterally (as has been happening). Unilateral tariff reductions mean that at a stroke a customs union is turned into a free trade area - assuming that intraregional trade is still tariff-free $e^{55}$ - and a free trade area is an inferior animal to a customs union. In particular, the ability of one country to import goods from outside the region at a lower tariff than applies in other countries lowers nominal tariff protection for all countries, but may not lower effective protection for the country reducing tariffs unilaterally. Sooner or later, such a situation is bound to invite retaliation (probably in the form of non-tariff barriers in intraregional trade).

Thus, the pursuit of tariff reductions within a multilateral regional framework is a very high priority. The goal should be a Common External Tariff (CET) with lower negotiated tariffs for all counties. The nature of multilateral negotiations means that the pace of tariff reductions may be faster than some countries would like and slower than others would prefer, but this is a small price to pay for maintaining a CET. The CET was the cornerstone of CACM's success in the 1960s, distinguishing it from the Latin American Free Trade Area (LAFTA), ${ }^{56}$ and its abandonment in the 1990 s would put at risk the future of regional integration.

With a lower CET, Central America should be able to avoid inefficient ISI. Not all ISI, however, is inefficient and a lower CET raises the prospect of efficient ISI in the region. The difference between inefficient and efficient ISI is not a simple matter, but it is determined fundamentally by a downward shift in the industry supply curve as a result of learning by doing. Thus, an industry where such a shift has not and will not take place is likely to be inefficient since it can never compete internationally without heavy tariff protection. An industry where such a shift has taken, or will take, place has the chance of 
competing internationally with only modest tariff protection.

Thus, efficient ISI is more likely where the supply curve is expected to shift downwards. However, the downward shift is not independent of tariff changes; the prospect of lower nominal tariffs forces firms to change working practices, eliminate waste and adopt new technology - all of which are likely to promote efficient ISI. These changes cannot be introduced in a vacuum and the authorities must be able to guarantee a framework in which firms not only have an incentive to modify work practices, but also have the resources do so.

It follows that tariff reductions, even through a lower CET, cannot be seen in isolation from other measures designed to promote industrial efficiency. A policy of tariff reduction on its own could eliminate both inefficient and efficient ISI since even the potentially efficient firms may not be able to compete. It is no accident that trade liberalisation policies work best in countries where the policies have been preceded by several years in which firms are given incentives to improve their efficiency through recapitalisation and labour training. This is an additional reason why trade liberalisation in Central America, as argued in the previous section, should be gradual in order to increase the chances of efficient ISI.

It was argued in the previous section that the best prospect for nontraditional exports to ROW lies with agroindustries. The latter require raw materials, which must be processed and in some cases reprocessed. The natural resource base is relatively limited for each Central American country, but is still substantial for the region as a whole. There are countries with a shortage of forests (e.g. Costa Rica) and others with a surplus (e.g. Honduras); there are republics with very high man/land ratios (e.g. El Salvador) and others with low ratios (e.g. Nicaragua). When decisions on agroindustries are taken at a national level, taking into account only raw materials available at the national level, the results are likely to be disappointing. Decisions need to be taken at the regional level, where the resource base is so much richer; intraregional trade in raw materials, relatively unimportant so far, could and should become a major component of commerce within Central America.

The existence of a marketed surplus of a given raw material is an obvious incentive for setting up an agroindustry to process it; indeed, it is a classic example of forward linkages. Similarly, the existence of a given agroindustry is an incentive to produce more raw materials through backward linkages. Clearly, the two processes are interdependent, but they are not automatic. In particular, if the agroindustries do not come into existence, then there is little chance of increased intraregional trade in raw materials and any marketed surplus will have to be sold abroad. 
Certainly, there are now additional incentives to set up agroindustries using regional raw materials. The strategy of non-traditional exports pursued by Costa Rica, for example, has created a richer natural resource base which could be exploited by firms throughout the region to capture value added through processing and export to ROW. However, there is now a case for reviving the old Integration Industries Scheme (IIS) which operated at the beginning of the 1960 s. $^{57}$ The IIS, which was designed to distribute new strategic industries equally among the five countries, suffered from the disadvantage that it created a regional monopoly. However, agroindustries exporting outside the region would not be subject to the same charge.

Under this new IIS scheme, certain agroindustries (perhaps those requiring particularly heavy capital investments) would be designated as integration industries and would be allocated among the member countries of CACM. A beneficiary of the scheme would be protected from competition within the region, but would have to sell most of its output to ROW. The absence of regional competition would provide a greater guarantee of access to raw materials in sufficient quantity needed to mount the kind of large-scale investments required to capture economies of scale in agroindustries.

Clearly, the IIS scheme should not be used for all agroindustries. Although the problem of regional monopoly disappears if the output is sold abroad, there is still the problem of a regional monopsony as the industry would be the major buyer of certain raw materials. However, the IIS remains a very effective way of making sure that all members of CACM enjoy at least some of the net gains from regional integration. After its de facto collapse in the mid-1960s, CACM never found an alternative instrument that could be so effective in distributing regional benefits.

Intraregional trade in agricultural products need not be confined to raw materials. There is also a strong case for increased intraregional trade in basic grains so that deficits and surpluses at the national level can be matched at the regional level. This has long been a goal in Central America, ${ }^{58}$ but it was never realised because cheap food policies led in the past to duty-free imports or food aid under PL480 and other measures. The balance of payments crisis in the 1980s, however, reached such intensity that even food imports have been affected. The result has been a number of import restrictions which have promoted import substitution in agriculture (ISA).

It is generally accepted that much of this ISA, including in basic grains, leads to production at unit costs higher than those prevailing in international markets. It may be possible to justify this in terms of the low opportunity costs of the factors of production used in ISA and the high opportunity cost of the 
foreign exchange saved. However, just as with efficient ISI, it is preferable to promote efficient ISA. This could be more easily achieved through increased trade in basic grains at the regional level. In turn, regional trade in basic grains requires the elimination of various non-tariff barriers within $\mathrm{CACM}{ }^{59}$

Regional cooperation is also possible in a whole host of areas including energy supply, road systems and telecommunications. These areas have in the past attracted cooperation through CACM. New areas for cooperation outside the framework of CACM include international shipping, air cargo transport, marketing in third countries and a common negotiating position in international fora (e.g. International Coffee Agreement, GATT, European Community).

Cooperation in these areas has hardly begun and it is still not uncommon to find the five republics adopting very different positions (as happened at the October 1989 meeting of the International Coffee Organisation), but the potential benefits from cooperation are enormous.

\section{The Internal Market}

The national market of each Central American republic, still very limited at the end of the 1970s, narrowed even further in the 1980s as a result of the fall in real GDP per head and the increased concentration of income and wealth. Many studies now suggest that a majority of the population in some countries is living in poverty.

Poverty on this scale leads to immense social and political problems. However, it is also an economic problem since it narrows the effective market in Central America from 25 million to, say, 10 million. This is not much more than the population of Guatemala on its own and reduces the chances that firms will be able to exploit economies of scale.

The traditional method of tackling poverty in Central America has been indirect, through the fiscal system and other redistributive mechanisms. It has manifestly failed to work, given the extent of poverty in the region, and the reasons are not hard to find. Even in rich countries, indirect methods of poverty alleviation through redistributive taxes have not in general been very effective and this is likely to be even more true of a region, such as Central America, where only a tiny proportion of the population pays direct (income) taxes.

In the context of the 1990 s there are other reasons for pessimism regarding an indirect assault on poverty via the tax system. The lack of confidence in the 
public sector and public sector institutions in many parts of the region does not give one confidence in the administrative capability of the state to carry out the necessary measures.

It follows that the assault on poverty, the improvement in income distribution and the widening of the effective market is more likely to succeed if carried out directly rather than indirectly. In other words, the allocation of resources at the point of production needs to favour these goals.

The proposals made in the previous two sections for promoting international and regional trade were designed to be consistent with poverty reduction. Agroindustrial exports to ROW, for example, using raw materials produced in the region, are likely to be labour-intensive if the indirect as well as direct employment effects are included in the calculations; gradual and selective trade liberalisation policies are consistent with the promotion of industries which give priority to higher labour productivity through training programmes.

However, these measures in themselves are probably not sufficient. Although the private sector almost certainly does provide the key to poverty reduction in the 1990s (the main task facing the public sector is to increase its efficiency), it is essential to remember that there are two private sectors; the first (P1) is essentially the formal sector, while the second (P2) consists of microempresas, artesanía, cooperatives, minifundias etc. Unless the existence of P2 is explicitly recognised, the benefits of renewed growth may be disproportionately captured by $\mathrm{P} 1$ without any significant reduction in poverty.

There are some parts of P2 which can be incorporated into the proposed long-run model of development quite easily. There is no reason, for example, why artesanía should not benefit from the promotion of non-traditional exports; similarly, minifundias should be able to participate in increased regional trade in basic grains, while producer cooperatives are not intrinsically at any disadvantage in the supply of raw materials for agroindustry.

The potential benefits of the model, however, will be foregone if P2 is prevented from taking part in economic expansion as a result of various supplyside bottlenecks. These include the absence of credit for working capital, lack of knowledge about foreign markets and the shortage of training programmes for the necessary new skills.

The traditional proposal for solving these problems and eliminating the bottlenecks usually involves an increased role for the state. There is no doubt that state participation is important in eliminating bottlenecks faced by $\mathrm{P} 2$, but in the context of the reduced administrative capacity of the public sector it is 
probably not sufficient. It is therefore important to try and channel the combined resources of the Non-Governmental Organisations (NGOs) operating in the region towards this problem. The aggregate presence of the NGOs in Central America is considerable; they do not have the financial resources of the multilateral agencies, but they do have enormous flexibility and enjoy considerable support among the population at large. They are therefore ideally suited to channelling resources and implementing programmes among the thousands of tiny establishments that make up P2.

There are still many individuals and families, currently living in poverty, who may not be touched by any of these proposals. They may be un- or underemployed, virtually outside the market economy and dependent on transfers from relatives or on begging. Economic growth in general cannot be relied on to eliminate this problem, since 'trickle-down' (derrame) has not proved efficacious in Central America.

The main source of transfers to such groups since the mid-1980s has almost certainly been remittances from relatives living outside the country (usually in the United States). Estimates differ, but the value of remittances for the region as a whole is probably around $\$ 1,000$ million annually compared with commodity exports of $\$ 4,500$ million. Thus, these remittances are already a major source of foreign exchange (the major source in El Salvador); furthermore, they can be expected to grow in the 1990s since the numbers of Central Americans living abroad is not likely to diminish significantly and their average earnings can be expected to rise.

The remittances have undoubtedly alleviated poverty in Central America. However, they have not done much to eliminate poverty because they have not been used efficiently. The bulk of the remittances (over 80 per cent) is spent on non-durable consumption and the remainder is often spent on paying off debts. Of course, some increase in non-durable consumption from remittances is both inevitable and desirable, but what is not acceptable is that a major source of foreign exchange earnings should have virtually no impact on capital accumulation. Thus, virtually nothing is available for increasing the capital stock per worker which in the long-run is the most effective way of reducing poverty. Furthermore, the dollars are sold on the black market and provide a vehicle for capital flight.

It is therefore essential that these remittances are captured through the financial system in such a way that they prevent capital flight and promote investment (in fixed, working and human capital) by the recipients. Again, it is possible that the NGOs, together with the Churches, could play a role. Furthermore, the details of such schemes must clearly be worked out at the 
local level, where NGOs and Churches are often the only institutions with the necessary detailed knowledge. This is not to deny that both the state and P1 have a role to play in formulating a financial system which can help to capture the remittances in an efficient way, but simply to recognise that the problem will require an unconventional approach if recipients of remittances are to be persuaded to use a proportion of the receipts for the purpose of financial or real investment. $^{60}$

\section{Conclusions}

This paper began with the statement of a number of goals which any long-run model of development for Central America must set itself. It is worth stressing, therefore, how and why the model outlined here can contribute towards the fulfilment of those goals.

The target of rapid recovery of real GDP per head is met by a model which emphasises the complementarity between the national, regional and international markets. In the model, the expansion of one source of demand does not imply a reduction in other sources of demand. The preferred policies are consistent with the simultaneous expansion of the three markets.

The target of income redistribution coupled with poverty reduction is to be achieved through a new allocation of resources across sectors and industries favouring those where the direct and indirect employment multiplier is high. At the same time, special measures need to be adopted towards the non-formal sector (P2) to ensure that it shares in the benefits of economic expansion.

The industrialisation project is promoted in a variety of ways. First, the spread of agroindustries contributes to the creation of new industries able to capture additional value added from the exploitation of regional raw materials. Secondly, efficient ISI within the CACM leads to the introduction of new industries which initially sell their output under the protection of the new CET. Thirdly, the strategy of gradual and selective trade liberalisation leads to the promotion of manufactured exports where comparative advantage is derived from wage costs (including skilled labour).

The goal of introducing a certain autonomous technological capability is achieved through the need to find new ways to exploit the processing of raw materials to satisfy the changing tastes of consumers in developed countries, through the need to compete in the markets for international services and through the opportunities for basing comparative advantage on skilled labour. 
The target for food self-sufficiency at the regional level is achieved through import substitution in agriculture in general and intraregional trade in basic grains in particular. In addition, the promotion of non-traditional exports will create an increased variety of foodstuffs (including fruits and vegetables) which can satisfy changes in regional demand.

The main constraint on the model identified ex ante was the balance of payments. This constraint is tackled in the model through both import substitution and export promotion; import substitution takes place at the regional level in both agriculture and industry, while export promotion takes place at the national level in non-traditional goods and services.

No effort has been made to incorporate the environmental constraint into the model formally. Instead, it has been stressed that development in the 1990s must be 'sustainable', i.e. the model must be consistent with the maintenance, if not improvement, of the environment.

In view of the damage to the environment in the last 40 years in Central America and the continuing pressures tending towards environmental destruction, it may be necessary to adopt an accounting framework which explicitly acknowledges the environment as a factor of production and calls for expenditure on repair and maintenance to preserve the value of environmental capital. There are several such schemes currently under discussion. ${ }^{61}$

The United Nations System of National Accounts (SNA) does not yet allow for the impact of development on the environment. It is also difficult to use the SNA for a direct attack on poverty since the target groups are not adequately represented. It is, therefore, appropriate to use a Social Accounting Matrix (SAM) approach, which can be used not only to monitor environmental problems but also to target rural and urban groups at risk from poverty. This also makes possible the construction of computable general equilibrium (CGE) models for the region, which experiment with changes in instruments such as tariffs to assess their impact on targets such as poverty reduction.

Energy supply was mentioned as a constraint on the model. It is easier to match supply and demand at the regional rather than national level and the model calls for cooperation within the framework of CACM to reduce national imbalances. Some projections, however, suggest that all five countries may face national deficits by the year 2000 so that even regional cooperation will not be sufficient. Faced with this problem, the need for an autonomous technological capability becomes even more pressing than ever since energy demand can always be modified through appropriate technological changes at the establishment level. 
Although most of the analysis in this paper has been conducted at the regional level, it would be inappropriate to conclude without a number of observations at the national level. The five republics are not the same and the differences do affect the conclusions.

Two republics (Nicaragua and El Salvador) will have to concentrate for the first half of the 1990s on economic reconstruction, i.e. rebuilding that part of their economy which has been wiped out in the 1980s. Thus, in the case of these two republics a concentration on traditional exports is legitimate since in both cases output is far below the previous peaks.

Trade liberalisation policies will not lead to the same pattern of new export activities in each country. While Costa Rica will find itself at a comparative disadvantage in maquila industries as a result of its relatively high labour costs and unfavourable geographical location (furthest from the USA), the opposite is likely to be true of Guatemala and El Salvador where the net foreign exchange receipts from maquiladoras could be significant. Guatemala is also the country likely to gain most from handicraft exports, although El Salvador also has reasonable prospects in this area.

Costa Rica is likely to have the best future in exports of services (other than tourism) in the 1990s. The reason is the intimate connection between success in this area and labour force skills; tourism, however, remains a major possibility in Guatemala, if the problem of political instability is resolved, and in Honduras, particularly now that the problem of an uncompetitive exchange rate seems to have been overcome.

Under a revived IIS, all five countries would benefit from the growth of agroindustries exporting to ROW. Without the IIS, the major beneficiaries would be those countries capable of raising the finance for the necessary investments; the most likely countries to benefit would be Costa Rica and Guatemala. Since these two countries are already the ones most likely to benefit from a revival in CACM, this emphasises the need for mechanisms such as the IIS for ensuring that all countries share in the net gains.

Intraregional trade in basic grains and raw materials creates special opportunities for Honduras and Nicaragua in view of their relative advantages in terms of access to fertile land, abundant supplies of cheap labour (at least after demobilisation in Nicaragua) and a small farm sector with title to land. Guatemala could also benefit from this aspect of intraregional trade.

All five countries can expect to gain from efficient ISI within the CACM following tariff reductions. While some high cost inefficient ISI will be put at 
risk, particularly in Honduras, the reduction of external tariffs on imported inputs will allow firms to consider production of goods previously considered uneconomic, while those existing firms that do survive trade liberalisation will be well placed to increase production within an expanding regional market.

The greatest problem could be faced by El Salvador, which has no surplus land, a desperate shortage of finance for investment and a poorly trained labour force. This emphasises yet again the special role played by remittances in $\mathrm{El}$ Salvador, since the scale of remittances in El Salvador makes them quantitatively and qualitatively different from elsewhere in the region. Indeed, one is forced to conclude that the more efficient use of remittances is an essential condition for ensuring that El Salvador has a realistic chance of meeting the model's targets in the next decade. 


\section{NOTES}

1. I have developed this argument at greater length in Bulmer-Thomas, V., Studies in the Economics of Central America (London: Macmillan; New York: St. Martin's Press, 1988), chapter 1.

2. See, for example, European Institute of Public Administration, 1992 and Central America: Impact and Issues, 1990.

3. Numerous studies by the United Nations, Economic Commission for Latin America and the Caribbean (ECLAC), have drawn attention to the extent of poverty in Central America in the 1980s. See, for example, Los Retos de una Política de Ataque Frontal a la Pobreza en Centroamérica (LC/MEX/R.157), Mexico, May 1989.

4. On environmental resource management in Central America, see US AID, Environmental and Natural Resource Management in Central America (ROCAP, Guatemala, 1989).

5. Details of the Brady Plan for Costa Rica can be found in ECLAC, Preliminary Overview of the Economy of Latin America and the Caribbean 1990 (Santiago, December 1990), p. 37.

6. On stabilisation and adjustment programmes in the first half of the 1980s, see Bulmer-Thomas, V., The Political Economy of Central America since 1920 (Cambridge: Cambridge University Press, 1987), chapter 11.

7. See Interamerican Development Bank, Economic and Social Progress in Latin America 1990 Report (Washington DC, 1990), Table B-2, p. 265.

8. On the forecast decline in US official capital flows to Central America, see USAID, Economic Assistance Strategy for Central America 1991 to 2000 (Washington DC, January 1991).

9. Known as the Oliveira-Tanzi effect, the impact of accelerating inflation on real tax receipts was also responsible for the collapse of the ratio of government revenue to GDP in Argentina and Peru in the late 1980s. 
10. 'Crowding-out' refers to the risk that public investment will exhaust available sources of finance for private investment. 'Crowding-in' refers to the complementarity between public and private investment. Negative 'crowding-in' therefore refers to the (complementary) fall in private investment that will follow a decline in public investment.

11. The phrase 'Washington consensus' has become famous following the publication of an influential book on policy reform in Latin America by John Williamson. See Williamson, J. (ed.), Latin American Adjustment: How Much has Happened? (Washington, DC: Institute for International Economics, 1990).

12. The strength of the Salvadoran currency has even led to suggestions that the country is suffering from 'Dutch disease' - a phenomenon more commonly associated with energy exporters.

13. The Cooperation Agreement, signed between the European Community (EC) and the Central American republics (with the addition of Panama) in 1985, has provided for an increase in mulitilateral aid to the region in every year. Although less than the cumulative total of bilateral aid from the $12 \mathrm{EC}$ members, multilateral aid is more important than bilateral aid from any single country and reached approximately $\$ 150$ million in 1990 .

14. In May 1991, the Nicaraguan government reached agreement with members of the Paris Club on repaying arrears to multilateral agencies which rendered the country eligible again for loans from the World Bank and the Inter-American Development Bank (no arrears were accumulated with the IMF by the Sandinistas).

15. For Latin America as a whole capital flight was reversed in 1989 and 1990 with a positive net inflow. However, almost all the increase was explained by capital repatriation in Chile and Mexico - the two countries which had adjusted most successfully in the 1980s. See Latin Finance, May 1991, p. 7.

16. The International Coffee Agreement (ICA) collapsed at the end of 1988. Prices fell sharply as supply was no longer constrained by export quotas. Producers of high quality coffee, however, experienced a relatively modest drop in price. Guatemalan and Salvadoran exporters in particular were able to compensate for the fall in price by expanding the volume sold and even increased the total value of coffee exports.

17. At present the tariff on bananas applied by the twelve members of the European Community varies from 20 per cent to zero. The formation of a single market requires harmonisation of all tariffs. In theory, this could mean 
a tariff for the whole EC of anything between 0 and 20 per cent. However, the EC members are obliged under GATT rules not to increase any existing tariffs; furthermore, under the Uruguay round negotiations the EC has already committed itself to eliminating tariffs on tropical agricultural products. It seems more likely, therefore, that tariffs will be harmonised downwards rather than upwards.

18. See the Report of the International Commission for Central American Recovery and Development, Poverty, Conflict and Hope - A Turning Point in Central America (Durham: Duke University Press, 1989), p. 113, table 1.

19. A countervailing duty was applied against US imports of Costa Rican cut flowers in the mid-1980s despite the fact that the "subsidies" which had provoked the retaliatory action had been awarded to exporters with the approval of US AID and other international agencies.

20. Lomé IV has now been signed and will last for ten years so that the Lomé agreement is now assured of an existence until the end of the century. Lomé IV does not differ substantially from Lomé III, although total transfers from the $\mathrm{EC}$ are set to rise by nearly 50 per cent.

21. The Bush Initiative, launched soon after President Bush came to power, proposed a series of reforms in US-Latin American relations. However, the one which caught the Latin American imagination was the offer of a free trade agreement (FTA) stretching form one end of the Americas to the other. With the FTA between Mexico and the USA expected to be in place by 1993, Central American countries were anxious not to be excluded from an integration scheme which raised the prospect of trade diversion (e.g. US duty-free imports from Mexico of goods previously purchased from Central America). At a meeting in Tuxtla Gutiérrez in January 1991, President Salinas de Gortari of Mexico responded positively to Central American concerns and offered to work towards the eventual inclusion of Central America in a broader FTA.

22. There is some uncertainty regarding income distribution and poverty in Costa Rica in the 1980s. Nevertheless, even in Costa Rica real wages at the end of the 1980s (based on average remunerations declared by persons covered by the social security system) were still 15 per cent below the level at the beginning of the decade. See ECLAC, Preliminary Overview, Table 6.

23. Maize can be purchased from Texas more cheaply, but it cannot necessarily be grown more cheaply. This is due to the distortions in agricultural prices in the USA, as in other developed countries, as a result of farm subsidies. 
24. On the energy balance in Central America, see Naciones Unidas, Comisión Económica para América Latina y el Caribe (CEPAL), Istmo Centroamericano: evolución y perspectivas del subsector eléctrico y posibilidades para lograr una mayor integración (1980-2000), LC/MEX/L.144, México, October 1990.

25. See Naciones Unidas, Plan Especial de Ccoperación Económica para Centroamérica (A/42/949), April 1988.

26. See, for example, Pearce, D. et al., Sustainable Development: Economics and the environment in the Third World (London: Edward Elgar, 1990).

27. For a good survey of environmental questions in Central America, see Robert Healy, 'A Reconaissance of Conservation and Development Issues in Central America', in William Ascher and Ann Hubbard (eds.), Central American Recovery and Development, Task Force Report to the International Commission for Central American Recovery and Development (Durham: Duke University Press, 1989).

28. For an excellent discussion of World Bank conditionality, see Paul Mosley, Jane Harrigan and John Toye, Aid and Power, the World Bank and Policy-Based Lending, Vol. 1 (London: Routledge, 1991).

29. This is true for most Latin American countries, not just those in Central America. See Alan Roe and Paul Popiel, The Restructuring of Financial Systems in Latin America (Washington, DC: Economic Development Institute of the World Bank, 1990).

30. There are several important articles on the educational system in Central America in Estudios Sociales Centroamericanos, No. 53 (May-August 1990, San José, Costa Rica).

31. See María Eugenia Gallardo, Centroamérica 1988-1995: Escenarios Económicos, Cuadernos de Ciencias Sociales No. 35, FLACSO, San José, 1991.

32. Since maquiladoras and the whole maquila industry concentrate on assembling imported inputs for export, the scope for industrial processing is very limited. Even in Mexico, the Latin American country with the most advanced maquila industry, the proportion of inputs purchased locally is very small. See Leslie Sklair, Assembling for Development: The Maquila Industry in Mexico and the United States (London: Unwin Hyman, 1989).

33. Some would argue that it is no longer even a Free Trade Area in view of the numerous non-tariff barriers that exist in trade between member countries. 
34. Evidence is still only circumstantial, but it is now well established that the beneficiaries of Certificados de Abono Tributario (CATs) - used to promote nontraditional exports - have been very concentrated. In fact, eight large firms received nearly 30 per cent of all CATs by value between March 1988 and September 1989. See La Nación, San José, 22 December 1989, p. 5A.

35. Some members of the Sanford Commission (including Arnold Harberger) were unable to give full and unequivocal support to the Commission's conclusions for this reason. See The Report of the International Commission for Central American Recovery and Development (Durham, North Carolina: Duke University Press, 1989), pp. 129-30.

36. See Naciones Unidas, Comisión Económica para América Latina y el Caribe, Reconversión Industrial en Centroamérica (Mexico, 1991).

37. See, for example Hector Lindo-Fuentes, Weak Foundations - The Economy of El Salvador in the Nineteenth Century, 1821-1828 (Berkeley: University of California Press, 1990).

38. If contraband trade (particularly important between El Salvador and Honduras) were included, the total figures for intraregional trade would be higher.

39. When the CACM was flourishing, virtually all intraregional trade was financed through the Cámara de Compensación. By 1986, however, the proportion had fallen below 50 per cent and by 1989 it had fallen below one per cent. See Consejo Monetario Centroamericano, Situación Económica de los Países Centroamericanos en 1990 (San José, 1991).

40. As part of the Cooperation Agreement, the European Community agreed to provide financial support (beginning in 1991) for interregional trade with funding to be channeled through the Cámara de Compensación.

41. Although all Central American countries are net debtors to the rest of the world, Guatemala and Costa Rica are net creditors within the region as a result of their accumulated surplus on intraregional trade.

42. The import-intensity of intraregional exports is a key bottleneck hindering the expansion of intraregional trade. See Institute of Social Studies, Central America: Economic Performance during the 1980s and Perspectives for the Period 1989-1995. Report to the European Commission, The Hague, 1988. 
43. The clearest statement of the Bank's position (albeit in a 'confidential' report) can be found in The World Bank, Trade Liberalization and Economic Integration in Central America, Washington DC., March 1989.

44. Although recent documents from USAID refer to the advantages of regional cooperation, the agency is much more hesitant about regional integration. See, for example, USAID, op. cit.

45. In 1990 Guatemalan exports to CACM were almost 25 per cent of total exports while Salvadoran exports to CACM were almost 30 per cent of the total.

46. The Esquipulas peace process is the name given to the series of meetings between Central American presidents since 1986, which has emphasised the need for a peaceful resolution of all conflicts in the region. At the meeting in July 1991, economic integration in the region was given a high priority.

47. See The Report of the International Commission for Central American Recovery and Development, op. cit.

48. Even in Costa Rica, the republic which has had most success in the promotion of non-traditional exports, the role of manufactured extra-regional exports has been very modest.

49. Without a CET countries often feel the need of non-tariff barriers on intraregional trade to protect themselves from a possible surge in goods imported through the republic with the lowest tariffs.

50. The DICA was an imaginative scheme, but it failed because no solution was offered to the accumulation of intraregional debts. See Institute of Social Studies, op. cit.

51. The modest revival of CACM after 1986 was certainly helped by the use of barter (often called countertrade), but it is a very inefficient and timeconsuming process for the region's industrialists.

52. The agreement specifically addresses the problem of intraregional debts and a special fund has been opened for the weaker countries (Honduras and Nicaragua) to promote economic reactivation.

53. The agreement has had to overcome numerous problems, which helped to explain the long delay in implementation. Even after the scheme went into operation, however, not all participants in Central America were persuaded of its value. 
54. See, for example, Willmore, L., Water in Central America's External Tariff: a review of the evidence, Mexico, June 1989 (mimeo).

55. For a list of restrictions on intraregional trade, see SIECA, Inventario de Medidas Restrictivas al Comercio Intrazonal, Guatemala, September, 1989.

56. See, for example, Henry Finch, 'The Latin American Free Trade Association', in Ali El-Agraa (ed.), International Economic Integration, second edition (London: Macmillan, 1988).

57. See D. Ramsett, Regional Industrial Development in Central America: A Case Study of the Integration Industries Scheme, New York: Praeger, 1969.

58. See, for example, Secretaría Permanente del Tratado General de Integración Económica Centroamericana (SIECA), Protocolo Especial Sobre Granos (Protocolo de Limón), Guatemala, 1965.

59. Some authors are not persuaded that Central America will be able to feed itself. See, for example, Salvador Arias Peñate, ¿Seguridad o inseguridad Alimentaria? Un Reto para la Región Centroamericana: Perspectivas al Año 2000, Guatemala, 1989. Nevertheless, the elimination of non-tariff barriers within the region is an essential first step towards increasing regional food selfsufficiency.

60. Research along these lines was being carried out by Segundo Montes before his assassination in 1989. See Segundo Montes, Salvadoreños Refugiados en los Estados Unidos, Instituto de Investigaciones, Universidad Centroamericana José Simeón Cañas, San Salvador, 1989.

61. See, for example, David Pearce, op. cit. 


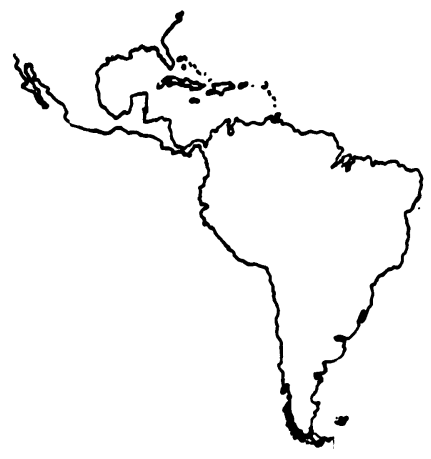

\section{Papers in this series may be obtained from the INSTITUTE OF LATIN AMERICAN STUDIES}

31, Tavistock Square, London WC1H 9HA

Price per copy, including postage:

Vols $1-20$

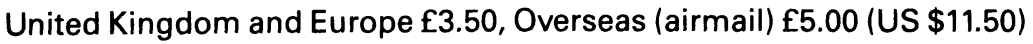

Vols 21-

United Kingdom and Europe $£ 4.50$, Overseas (airmail) $€ 7.00$ (US $\$ 14.00$ )

Please make cheques payable to The University of London 
